Article

\title{
Impact of EU Environmental Policy Implementation on the Quality and Status of Greek Rivers
}

\author{
Nikolaos Theodor Skoulikidis ${ }^{1, *} \mathbb{( \mathbb { D }}$, Ioannis Karaouzas ${ }^{1} \mathbb{D}$, Yorgos Amaxidis $^{1}$ and Maria Lazaridou ${ }^{2}$ \\ 1 Hellenic Center for Marine Research, Institute of Marine Biological Resources and Inland Waters, \\ 19013 Attika, Greece; ikarz@hcmr.gr (I.K.); gamax@hcmr.gr (Y.A.) \\ 2 Department of Zoology, School of Biology, Aristotle University, 54006 Thessaloniki, Greece; \\ mlazarid@bio.auth.gr \\ * Correspondence: nskoul@hcmr.gr
}

Citation: Skoulikidis, N.T.;

Karaouzas, I.; Amaxidis, Y.;

Lazaridou, M. Impact of EU

Environmental Policy

Implementation on the Quality and

Status of Greek Rivers. Water 2021, 13,

1858. https://doi.org/10.3390/

w13131858

Academic Editor: Matthias Zessner

Received: 27 May 2021

Accepted: 30 June 2021

Published: 3 July 2021

Publisher's Note: MDPI stays neutral with regard to jurisdictional claims in published maps and institutional affiliations.

Copyright: (c) 2021 by the authors. Licensee MDPI, Basel, Switzerland. This article is an open access article distributed under the terms and conditions of the Creative Commons Attribution (CC BY) license (https:/ / creativecommons.org/licenses/by/ $4.0 /)$.

\begin{abstract}
Based on historical and WFD-compliant data, the recent inter-annual ecological status and the long-term chemical-physicochemical quality trends of eighteen characteristic Greek rivers have been assessed and interpreted in view of implementing EU environmental policies and the evolution of human pressures. Considering predominating poor ecological status in most of the river outflows, the strengths and weaknesses of the WFD implementation have been highlighted. The long-term decrease of ammonium and nitrite concentrations along with relatively low recent $\mathrm{BOD}_{5}$ levels, indicate a general improvement of WWTP infrastructure in Greece and the other riparian countries, whereas the improvement of nitrate quality is attributed to the reduction of fertilizers use, and possibly, to the successful application of the Nitrates Directive in certain basins. Despite capacity building in governance and administrative infrastructure the recent years, River Basin Management Plans (RBMPs) are being implemented centrally, largely mechanistically, with minor public participation. Regarding WFD implementation weaknesses and gaps, concrete proposals have been formulated considering both policy/administrative and technical issues. To efficiently conserve and restore aquatic ecosystems, the forthcoming RBMPs should be consistent with ecosystem services principles focusing on nature-based solutions, along with changing attitudes of the state authorities and the public.
\end{abstract}

Keywords: Greece; WFD; chemical-physicochemical quality; ecological status; River Basin Management Plans; restoration; EU legislation; environmental policy

\section{Introduction}

Introduced in 2000 to reform and rationalize water policy and management across the European Union (EU), the Water Framework Directive 2000/60/EC (WFD) is the cornerstone of the EU's water policy. As the driver of new, enhanced ecological assessment methods, it greatly improved the monitoring and assessment of ecological status (ES) of water bodies (WBs), thereby providing a better basis for restoration [1] in the frame of River Basin Management Plans (RBMPs). It has also been successful in setting up a governance framework for integrated water management for the more than 110,000 WBs in the EU, decelerating the deterioration of water status and reducing (mainly point source) chemical pollution [2]. It also provided countries, that traditionally lag regarding environmental issues, such as the Balkans [3], the opportunity to meet and set ecosystems' monitoring, conservation, and restoration among their national priorities. Being, however, the most ambitious piece of environmental legislation ever enacted in the EU [4], member states were not successful in materializing their ultimate objective, i.e., achieving good status of Europe's waters [5]. Its implementation has been significantly delayed, and less than half of the EU's WBs are in good status, even though the deadline for achieving this was 2015 [2]. 
Due to its turbulent history, environmental research and conservation in Greece were long ignored, and economic growth was prioritized at the expense of environmental conservation [6,7]. National hydrological monitoring programs started in the $1960^{\prime}$ s, connected to hydropower development (Public Power Corporation, PPC), and hydrochemical ones in the 1970 's, connected to agricultural development. A national ecological monitoring program was initiated only after the WFD. Before implementing the WFD, freshwater monitoring was conducted by various ministries, local authorities, academic and research institutions, while each network density, the time-step, and the period of the measurements depended on the corresponding special needs and funding [8]. However, even by individual efforts, and often outside the scope of the respective research program, Greek scientists collected aquatic ecological data, during the last three decades, albeit geographically fragmented. European projects that aimed to assist member states in implementing the WFD, such as AQEM, STAR, and FAME, played a pivotal role in collecting ecological data with WFD-compliant methods [9]).

As a result of a highly complicated [10] and inefficient governmental structure, the implementation of the WFD in Greece started and continued to be implemented with significant delays. The restructuring of the Ministry of Environment and Energy (MEE) with the establishment of the Special Secretariat of Water in 2013, gave impetus to the whole process. Particularly important was the establishment of the National Committee on Waters (NCW) that acted as a consultant for the Special Secretariat of Water. This time, the second round of the RBMPs, which contained the results of the first round of the national monitoring program (NMP, 2012-2015), have been approved in 2017, i.e., with only two years delay. The NMP has been interrupted for three years, and currently, the second phase is running (2018-2023).

River water quality on a country-wide scale has been fairly studied in Greece, either focusing on physicochemical parameters, major ions, and nutrients [3,11-16] or trace elements and hazardous substances [3,16-20]. On the contrary, country-wide, or nearly country-wide studies regarding riverine ES are scarce and refer to times prior to implementing the NMP [21,22]. This study attempts to fill this gap by providing historical and up-to-date information on the ES of several representative Greek rivers dispersed throughout the country.

The third round of the RBMPs will start soon, and thus, it is important to account for the strengths and weaknesses of the implementation procedure. For that purpose, we use rivers as an example. The aims of this article are to (i) present the ES of a number of representative rivers and assess any interannual trends, in addition to long-term trends of nutrients and dissolved oxygen (DO) concentration, (ii) attempt to link these trends to implementing environmental policies and respective changes in human pressures, and (iii) present the strengths and weaknesses of the WFD implementation in Greece from a technical and administrative point of view and propose actions for the improvement of the implementation procedure.

\section{Materials and Methods}

\subsection{Study Area}

Greece is a small mountainous country with remarkably varied relief, complex geological structure, an intense distribution of microclimates, and diverse fluvial ecosystems. There are numerous, small to medium-sized mountainous rivers and streams, with flashy flow and sediment regimes, running through steep, narrow valleys and descending abruptly to the coast. Large lowland areas are scarcely diffused within prevailing thrust belts and related rift valleys and are drained by medium and large low-gradient high runoff perennial rivers, which frequently form extensive flood and deltaic plains. The main anthropogenic pressures are connected with municipal wastes, agriculture, i.e., agrochemical application, agro-industrial waste discharges, land reclamation, and related water management, and hydropower production, causing deterioration of aquatic quality and river habitats $[3,14,16]$. 
As a result of historical and social circumstances, Greece has been characterized by an inefficient public sector, high bureaucracy, and insufficient enforcement of environmental legislation $[2,3,16,23]$. Together with deficient environmental awareness, environmental research and conservation were long ignored [3], and thus, historical aquatic quality and ecology data are temporally and spatially fragmented. After significant delays, along with the progressive adaptation of the EU's environmental legislation and restructuring of public administration, Greece started systematic quantitative and qualitative aquatic monitoring in line with the demands of the NMP of the WFD $[3,16]$.

Figure 1 illustrates the examined river basins, and Table 1 presents their main physicogeographical and anthropogenic characteristics.

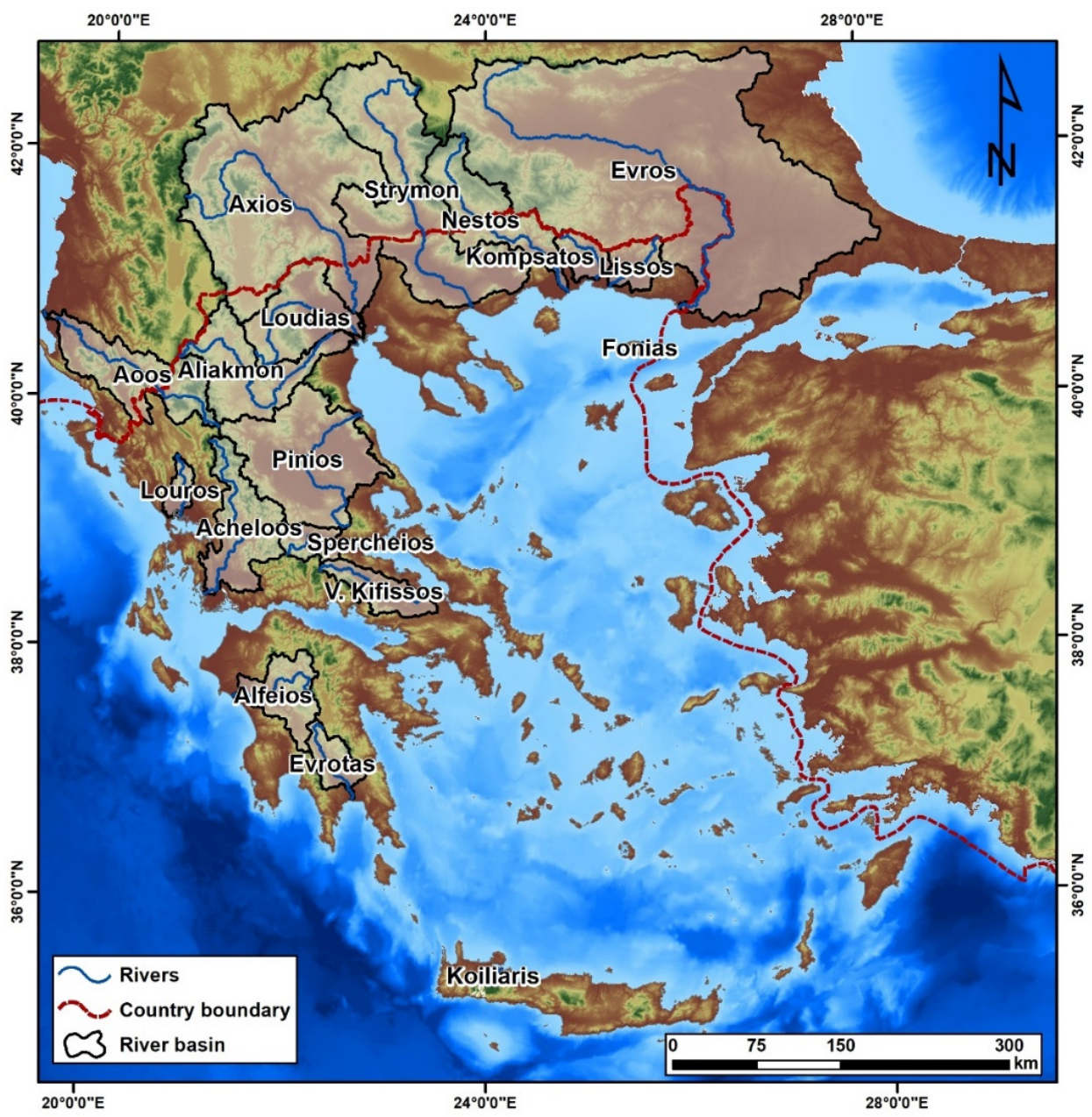

Figure 1. The examined river basins. 
Table 1. Physicogeographical and anthropogenic characteristic of the examined river basins.

\begin{tabular}{|c|c|c|c|c|c|c|c|c|c|c|c|c|c|c|c|c|}
\hline River & Country & $\mathrm{CA}^{1}$ & MCA $^{1}$ & $\mathrm{RL}^{1}$ & MAD $^{2}$ & MAP $^{3}$ & MAT $^{3}$ & & & & & $\mathrm{LU}^{5}$ & & $\mathrm{Nr}_{\mathrm{LD}}{ }^{6}$ & HPD $^{7}$ & GDP $^{8}$ \\
\hline & & $\mathrm{km}^{2}$ & $\mathbf{m}$ & $\mathbf{k m}$ & $\mathrm{km}^{3} / \mathrm{a}$ & $\mathrm{mm}$ & ${ }^{\circ} \mathrm{C}$ & Si & $\mathrm{Ca}$ & AS $\%$ & AA \% & F-SN \% & WB-W \% & & $\operatorname{inh} / \mathrm{km}^{2}$ & USD \\
\hline Evros & $\mathrm{GR} / \mathrm{TR} / \mathrm{BG}$ & 52,564 & 412 & 543 & 3.11 & 607 & 11.6 & + & & 4.1 & 55.7 & 39.1 & 1.1 & 215 & 65 & 23,686 \\
\hline Fonias & GR & 9.5 & 795 & 8 & 0.008 & 687 & 11.4 & + & & 0.0 & 1.48 & 98.52 & 0 & 0 & 16 & 0 \\
\hline Nestos & GR/BG & 6177 & 1047 & 258 & 1.06 & 603 & 8.8 & + & & 1.4 & 16.6 & 81.1 & 1.0 & 10 & 26 & 8360 \\
\hline Lissos & GR & 1844 & 303 & 87 & 0.17 & 595 & 12.8 & + & & 0.02 & 0.45 & 0.52 & 0.01 & 3 & 48 & 28,693 \\
\hline Kompsatos & GR & 1444 & 423 & 76 & 0.09 & 587 & 12.4 & + & & 0.02 & 0.29 & 0,64 & 0.05 & 1 & 65 & 19,536 \\
\hline Strymon & GR/BG & 16,803 & 719 & 366 & 1.67 & 556 & 10.3 & + & & 2.9 & 37.2 & 58.9 & 1.0 & 29 & 53 & 15,010 \\
\hline Axios & GR/NMK & 24,381 & 755 & 395 & 3.52 & 583 & 10.3 & + & & 2.1 & 40.7 & 56.6 & 0.5 & 33 & 83 & 12,106 \\
\hline Loudias & GR & 5685 & 624 & 187 & 0.73 & 530 & 11.9 & & + & 5.4 & 46.5 & 46.3 & 1.8 & 10 & 63 & 22,424 \\
\hline Aliakmon & GR & 6578 & 819 & 316 & 1.19 & 684 & 11.2 & + & & 1.7 & 37.2 & 59.0 & 2.2 & 27 & 28 & 16,392 \\
\hline Pinios & GR & 11,012 & 433 & 201 & 1.97 & 598 & 13.8 & + & & 2.7 & 50.8 & 45.4 & 1.1 & 25 & 49 & 21,067 \\
\hline Spercheios & GR & 1564 & 671 & 86 & 0.32 & 720 & 12.9 & + & & 2.5 & 29.2 & 68.0 & 0.4 & 0 & 52 & 16,257 \\
\hline Aoos & $\mathrm{GR} / \mathrm{AL}$ & 6651 & 845 & 249 & 4.51 & 1119 & 11.3 & & + & 2.4 & 18.5 & 78.6 & 0.5 & 1 & 19 & 15,552 \\
\hline Louros & GR & 931 & 397 & 88 & 0.38 & 948 & 14.4 & + & + & 3.2 & 38.5 & 54.1 & 4.2 & 1 & 39 & 18,727 \\
\hline Acheloos & GR & 6478 & 744 & 255 & 2.32 & 865 & 12.1 & & + & 1.5 & 18.3 & 75.4 & 4.8 & 6 & 25 & 24,242 \\
\hline V. Kifissos & GR & 2541 & 423 & 126 & 0.26 & 630 & 14.6 & & + & 2.7 & 46.2 & 49.6 & 1.5 & 0 & 38 & 34,128 \\
\hline Alfeios & GR & 3637 & 690 & 145 & 1.71 & 819 & 13.0 & & + & 1.7 & 38.6 & 59.4 & 0.3 & 1 & 17 & 22,285 \\
\hline
\end{tabular}

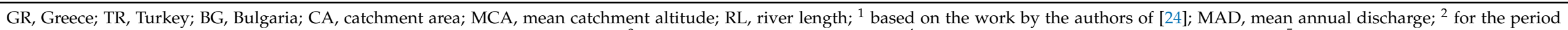

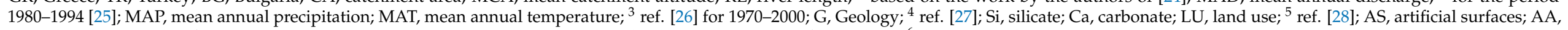

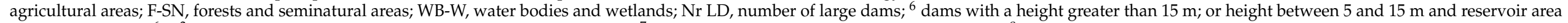
greater than $3 \times 10^{6} \mathrm{~m}^{3}$ [29], with modifications); HPD, human population density; ${ }^{7}$ ref. [30] for 2015; GDP, gross domestic product; ${ }^{8}$ ref. [31] for 2015. 


\subsection{Methods}

The rivers included in this study (Figure 1) were selected according to the availability of historical data, and these were mostly medium to very large. To provide a representative overview of the impact of multiple stressors on river quality, monitoring stations were selected to be located as close as possible to the river outflows. A total of 18 rivers (i.e., 18 monitoring stations) were considered, covering all Water Districts (WDs), apart from EL0014 (Aegean Island rivers), due to lack of consistent historical data.

River ecological data compliant with the recommendations of the WFD in Greece is limited to the NMP (2012-2015 and 2018-2019), and to sporadic research fulfilled prior to the NMP by the Aristotle University of Thessaloniki (AUTH, Dept. of Biology) or the Hellenic Centre for Marine Research (HCMR, Institute of Marine Biological Resources and Inland Waters). The presentation of the mean riverine ES base on the results of the NMP and includes hydromorphological, chemical-physicochemical (C-P), and largely, the whole set of biological quality elements (BQEs), i.e., fish and aquatic macroinvertebrates and flora. These data refer to two seasonal samplings per year regarding BQEs and to three seasonal samplings/measurements per year regarding C-P quality elements, according to the prescriptions of the NMP.

Previous ES assessments, carried out in the frame of European and National projects, were restricted to macroinvertebrate and C-P quality elements. Thus, to obtain comparable long-term results on ES, we used C-P quality elements and macroinvertebrates. For that purpose, a common database between HCMR and AUTH has been analyzed. Data sources of the database include European (e.g., AQEM, STAR, LIFE-EnviFriendly, MIRAGE, GLOBAQUA, etc.) and National projects, as well as the results of the NMP. Sampling stations of different data sources were selected to be identical or at least close to each other. Data prior to the NMP include variable annual sampling efforts.

The annual ES for years with more than two samplings resulted from the median value of seasonal (or monthly) efforts. Similarly, the multiple-year ES has been assessed as the median of individual years.

Biological quality indices for each BQE for the assessment of the ecological status included: The HESY2 (Hellenic Evaluation System 2) for benthic macroinvertebrates [32,33], the IPS (Specific Pollution Sensitivity) diatom index harmonized for Greece [34], the IBMR index for macrophytes adjusted for Greece [35], and the Hellenic Fish Index (HeFI) for fish fauna [36]. The C-P quality has been carried out using classification systems for nutrients and dissolved oxygen (DO) [37]. Hydrmorphological quality was assessed using the River Habitat Survey (RHS) [38].

To extend the period of aquatic quality investigations to the past, C-P data (nutrients and dissolved oxygen) were additionally used. Data for nutrients and DO come from the Ministry of Rural Development (MRDF), and the MEE and refer to monthly measurements of the period 1980-2011, the National Monitoring Program (2012-2015 and 2018-2019), and projects conducted by HCMR and AUTH in various rivers. Thus, data on C-P parameters extend up to 40 years. Annual nutrient and DO concentrations were calculated as averages of the monthly measurements. In-situ and laboratory methods applied in the frame of the NMPs are described in detail by the authors of [39]. To assess any historical changes in river water quality, two periods have been distinguished; 1980-2011 and 2012-2020. The lower boundary of the recent period coincides with massive installations of urban wastewater treatment plants (UWWTPs) in Greece [40].

To explore nutrient and DO relationships, cross-correlation analyses were carried out for the two periods using the Statistical Product and Service Solutions (SPSS) software [41]. A number of river data from the old time-series refer to total phosphorus (TP) (e.g., from the MRDF), whereas other data refer to $\mathrm{PO}_{4}$. However, a large data set from the second monitoring round (2018-2019) refer to both parameters that were significantly correlated. To fill gaps in measurements, the following equation has been applied: TP $=1.0517 \times \mathrm{P}-$ $\mathrm{PO} 4+0.0099\left(\mathrm{~N}=959, \mathrm{R}^{2}=0.998, p<0.001\right)$. 


\section{Results}

According to the results of the second RBMPs, which was based on the first NMP round (2012-2015) of the Greek river WBs (i.e., 1129 natural, 178 heavily modified, and 38 artificial WBs with known status), $68.2 \%$ presented a higher than good ES, with high ES accounting for only $0.9 \%$, whereas $24.2 \%$ showed a moderate ES, $6.5 \%$ a poor ES, and only $1.1 \%$ illustrated a bad ES [42].

Table 2 presents the ES of the selected rivers of this work, according to the results of the first round of the NMP (2012-2015) and the years 2018-2019 of the second round of the NMP using C-P (DO and nutrients), biological (macroinvertebrates, fish, aquatic macrophytes and diatoms) and hydromorphological quality elements.

Table 2. ES of the examined rivers near their outflows using C-P, biological (macroinvertebrates, fish, aquatic macrophytes, and diatoms), and hydromorphological quality elements, according to the first round of the NMP (2012-2015) and the years 2018-2019 of the second round of the NMP. G: good, M: moderate, P: poor, B: bad. Colors of ES correspond to the WFD prescriptions.

\begin{tabular}{cccccc}
\hline River & ES & River & ES & River & ES \\
\hline Evros & $\mathrm{B}$ & Axios & $\mathrm{P}$ & Aoos & $\mathrm{G}$ \\
\hline Fonias & $\mathrm{G}$ & Gallikos & $\mathrm{P}$ & Louros & $\mathrm{P}$ \\
\hline Nestos & $\mathrm{M}$ & Loudias & $\mathrm{P}$ & Acheloos & $\mathrm{M}$ \\
\hline Lissos & $\mathrm{P}$ & Aliakmon & $\mathrm{P}$ & V. Kifisos & $\mathrm{G}$ \\
\hline Kompsatos & $\mathrm{P}$ & Pinios & $\mathrm{P}$ & Alfeios & $\mathrm{M}$ \\
\hline Strymon & $\mathrm{P}$ & Spercheios & $\mathrm{M}$ & Evrotas & $\mathrm{P}$ \\
\hline
\end{tabular}

Table 3 presents the inter-annual variation of river ES based on C-P variables (DO and nutrients) and macroinvertebrates, including data prior to implementing the NMP.

Table 3. Inter-annual variability of riverine ES near the river outflows using C-P variables and macroinvertebrates. Data according to the NMP, Aristotle University of Thessaloniki (AUTH), and the Hellenic Centre for Marine Research (HCMR). C-PQ, chemical—physicochemical quality; BQ, biological quality. H: high, G: good, M: moderate, P: poor, B: bad. Colors of ES correspond to the WFD prescriptions.

\begin{tabular}{|c|c|c|c|c|c|c|c|c|c|c|c|c|c|}
\hline River & Year & $\mathrm{Nr}^{1}$ & C-PQ & BQ & ES & Source & River & Year & $\mathrm{Nr}$ & C-PQ & BQ & ES & Source \\
\hline \multirow[t]{3}{*}{ Evros } & 2015 & 3,2 & $\mathrm{M}$ & $\mathrm{M}$ & $\mathrm{M}$ & NMP & Aliakmon & 1995 & 11,11 & $\mathrm{M}$ & $\mathrm{M}$ & $\mathrm{M}$ & AUTH \\
\hline & 2018 & 2,2 & G & B & B & NMP & & 1997 & 1,1 & G & M & $\mathrm{M}$ & AUTH \\
\hline & 2019 & 3,2 & M & B & B & NMP & & 2012 & 1,1 & $\mathrm{G}$ & B & B & AUTH \\
\hline \multirow[t]{5}{*}{ Fonias } & 2000 & 3,3 & G & $\mathrm{H}$ & G & $\overline{\mathrm{HCMR}}$ & & 2013 & 2,1 & G & $\mathrm{P}$ & $\mathrm{P}$ & NMP \\
\hline & 2011 & 2,2 & $\mathrm{H}$ & G & G & AUTH & & 2014 & 3,2 & M & M & $\mathrm{M}$ & NMP \\
\hline & 2015 & 2,1 & $\mathrm{H}$ & $\mathrm{H}$ & $\mathrm{H}$ & NMP & & 2015 & 3,2 & M & M & $\mathrm{M}$ & NMP \\
\hline & 2018 & 4,2 & $\mathrm{H}$ & G & G & NMP & & 2018 & 3,2 & G & $\mathrm{P}$ & $\mathrm{P}$ & NMP \\
\hline & 2019 & 2,2 & $\mathrm{H}$ & G & $G$ & NMP & & 2019 & 3,2 & G & $\mathrm{P}$ & $\mathrm{P}$ & NMP \\
\hline \multirow[t]{7}{*}{ Nestos } & 2008 & 2,2 & $\mathrm{H}$ & $\mathrm{M}$ & $\mathrm{M}$ & AUTH & Pinios & 2002 & 2,2 & $\mathrm{M}$ & $\mathrm{M}$ & $\mathrm{M}$ & AUTH \\
\hline & 2012 & 2,1 & G & M & $\mathrm{M}$ & NMP & & 2012 & 2,1 & M & $\mathrm{M}$ & $\mathrm{M}$ & NMP \\
\hline & 2013 & 2,1 & G & M & $\mathrm{M}$ & NMP & & 2013 & 3,2 & $P$ & $\mathrm{P}$ & $\mathrm{P}$ & NMP \\
\hline & 2014 & 2,2 & $\mathrm{H}$ & M & $\mathrm{M}$ & NMP & & 2014 & 3,2 & G & G & G & NMP \\
\hline & 2015 & 3,2 & $\mathrm{H}$ & G & G & NMP & & 2015 & 3,2 & P & P & P & NMP \\
\hline & 2018 & 2,2 & $\mathrm{H}$ & $\mathrm{H}$ & $\mathrm{H}$ & NMP & & 2018 & 3,2 & G & $\mathrm{M}$ & $\mathrm{M}$ & NMP \\
\hline & 2019 & 2,2 & $\mathrm{H}$ & $\mathrm{H}$ & $\mathrm{H}$ & NMP & & 2019 & 3,2 & M & G & $\mathrm{M}$ & NMP \\
\hline \multirow[t]{3}{*}{ Lissos } & 2015 & 2,1 & $\mathrm{G}$ & $\mathrm{M}$ & $\mathrm{M}$ & NMP & Spercheios & 2014 & 2,1 & $\mathrm{G}$ & $\mathrm{G}$ & $\mathrm{G}$ & NMP \\
\hline & 2018 & 3,2 & G & $\mathrm{H}$ & G & NMP & & 2015 & 3,2 & M & $\mathrm{M}$ & $\mathrm{M}$ & NMP \\
\hline & 2019 & 3,3 & G & G & $\mathrm{G}$ & NMP & Aoos & 2000 & 3,3 & $\mathrm{H}$ & $\mathrm{H}$ & $\mathrm{H}$ & HCMR \\
\hline \multirow[t]{3}{*}{ Kompsatos } & 2000 & 3,2 & G & $\mathrm{P}$ & $\mathrm{P}$ & HCMR & & 2001 & 2,2 & $\mathrm{H}$ & $\mathrm{H}$ & $\mathrm{H}$ & AUTH \\
\hline & 2011 & 1,1 & G & $\mathrm{P}$ & $\mathrm{P}$ & AUTH & & 2013 & 3,2 & $\mathrm{H}$ & G & $\mathrm{G}$ & NMP \\
\hline & 2015 & 3,2 & $\mathrm{H}$ & M & $\mathrm{M}$ & NMP & & 2019 & 3,2 & $\mathrm{H}$ & $\mathrm{H}$ & $\mathrm{H}$ & NMP \\
\hline
\end{tabular}


Table 3. Cont.

\begin{tabular}{|c|c|c|c|c|c|c|c|c|c|c|c|c|c|}
\hline River & Year & $\mathrm{Nr}^{1}$ & C-PQ & $\mathrm{BQ}$ & ES & Source & River & Year & $\mathrm{Nr}$ & C-PQ & $B Q$ & ES & Source \\
\hline \multirow[t]{7}{*}{ Strymon } & 2008 & 2,2 & $G$ & $\widetilde{P}$ & $\mathrm{P}$ & AUTH & Louros & 2012 & 2,1 & $\mathrm{G}$ & $\bar{G}$ & $\mathrm{G}$ & NMP \\
\hline & 2012 & 1,1 & M & B & B & NMP & & 2013 & 3,2 & G & G & G & NMP \\
\hline & 2013 & 3,2 & M & M & $\mathrm{M}$ & NMP & & 2014 & 3,2 & G & $\mathrm{H}$ & G & NMP \\
\hline & 2014 & 3,2 & M & M & $\mathrm{M}$ & NMP & & 2015 & 2,2 & G & G & $\mathrm{G}$ & NMP \\
\hline & 2015 & 3,2 & M & B & B & NMP & & 2018 & 3,2 & G & G & G & NMP \\
\hline & 2018 & 3,2 & M & $\mathrm{P}$ & $\mathrm{P}$ & NMP & Acheloos & 2012 & 2,1 & $\mathrm{H}$ & M & $\mathrm{M}$ & NMP \\
\hline & 2019 & 3,2 & M & M & $\mathrm{M}$ & NMP & & 2013 & 3,2 & G & M & $\mathrm{M}$ & NMP \\
\hline \multirow[t]{8}{*}{ Axios } & 1997 & 11,11 & G & M & $\mathrm{M}$ & AUTH & & 2014 & 3,2 & $\mathrm{H}$ & G & $\mathrm{G}$ & NMP \\
\hline & 1998 & 1,1 & G & M & $\mathrm{M}$ & AUTH & & 2018 & 3,2 & $\mathrm{H}$ & G & G & NMP \\
\hline & 2000 & 3,1 & M & $\mathrm{P}$ & $\mathrm{P}$ & AUTH & & 2019 & 3,2 & $\mathrm{H}$ & $\mathrm{H}$ & $\mathrm{H}$ & NMP \\
\hline & 2012 & 1,1 & M & P & $\mathrm{P}$ & NMP & V. Kifisos & 2018 & 3,2 & $\mathrm{G}$ & $\mathrm{G}$ & G & NMP \\
\hline & 2013 & 3,2 & M & $\mathrm{P}$ & $\mathrm{P}$ & NMP & Alfeios & 2000 & 3,3 & M & M & $\mathrm{M}$ & HCMR \\
\hline & 2014 & 1,1 & M & B & B & NMP & & 2014 & 3,2 & G & G & $\mathrm{G}$ & NMP \\
\hline & 2018 & 3,2 & G & $\mathrm{P}$ & $\mathrm{P}$ & NMP & & 2015 & 3,2 & G & $\mathrm{H}$ & G & NMP \\
\hline & 2019 & 3,2 & M & $\mathrm{P}$ & $\mathrm{P}$ & NMP & & 2018 & 3,2 & P & M & $\mathrm{P}$ & NMP \\
\hline \multirow[t]{3}{*}{ Gallikos } & 2013 & 3,2 & G & M & M & NMP & & 2019 & 3,2 & $\mathrm{P}$ & G & $\mathrm{P}$ & NMP \\
\hline & 2018 & 3,2 & $\mathrm{G}$ & G & G & NMP & Evrotas & 2006 & 2,2 & M & $\mathrm{P}$ & $\mathrm{P}$ & HCMR \\
\hline & 2019 & 3,2 & G & G & G & NMP & & 2010 & 2,2 & M & G & $\mathrm{M}$ & HCMR \\
\hline \multirow[t]{6}{*}{ Loudias } & 2012 & 1,1 & M & B & B & NMP & & 2013 & 2,2 & G & M & $\mathrm{M}$ & NMP \\
\hline & 2013 & 3,2 & $P$ & $\mathrm{P}$ & $\mathrm{P}$ & NMP & & 2018 & 3,2 & G & G & G & NMP \\
\hline & 2014 & 3,2 & $\mathrm{P}$ & $\mathrm{P}$ & $\mathrm{P}$ & NMP & & 2019 & 3,2 & G & $\mathrm{H}$ & G & NMP \\
\hline & 2015 & 3,2 & M & $\mathrm{P}$ & $\mathrm{P}$ & NMP & & & & & & & \\
\hline & 2018 & 3,2 & $\mathrm{P}$ & M & $\mathrm{P}$ & NMP & & & & & & & \\
\hline & 2019 & 3,2 & $\mathrm{P}$ & M & $\mathrm{P}$ & NMP & & & & & & & \\
\hline
\end{tabular}

${ }^{1}$ number of seasonal samplings; $x$, C-P quality elements; $y$, macroinvertebrates. Assessments out of the NPM refer to the work by the authors of [43] (Aliakmon), ref. [44] (Axios, Aliakmon), ref. [21] (Kompsatos, Aoos, Alfeios), ref. [45] (Axios), ref. [46] (Aoos), ref. [47] (Nestos), ref. [48] (Kompsatos), refs. [39-50] (Fonias), and [51] (Evrotas).

The ES of the examined rivers ranged between good and bad, with poor status predominating (Table 2), and no clear inter-annual trends are visible (Table 3). Only the Nestos and Acheloos show a possible improvement, and the Alfeios a worsen of ES throughout the examined years.

Correlation analysis showed statistically robust relationships among certain nutrient species and DO. Within the old time series (1980-2011), the following relationships were evident; nitrate with ammonium $(\mathrm{R}=0.782, p<0.001)$ and nitrite $(\mathrm{R}=0.600, p<0.05)$, as well as ammonium with nitrite $(\mathrm{R}=0.665, p<0.005)$ and $\mathrm{DO}(\mathrm{R}=-0.594, p<0.05)$. In the recent time series all nutrients were significantly correlated; nitrate with nitrite $(\mathrm{R}=0.802, p<0.001)$, ammonium $(\mathrm{R}=0.779, p<0.001), \mathrm{TP}(\mathrm{R}=0.771, p<0.001)$ and phosphate $(\mathrm{R}=0.750, p<0.001)$, phosphate with ammonium $(\mathrm{R}=0.794, p<0.001)$ and nitrite $(\mathrm{R}=0.832, p<0.001)$, and TP with nitrite $(\mathrm{R}=0.836, p<0.001)$ and ammonium $(\mathrm{R}=0.788, p<0.001)$. In both time series, phosphate and TP were strongly correlated $(\mathrm{R}=0.818$ and 0.997 , in the old and new time-series, respectively, both at $p<0.001)$, but this was partly due to the fact that data gaps were filled using the equation presented in Section 2.2.

Table 4 illustrates the average concentrations of DO and nutrients for two periods (1980-2011 and 2012-2020) and their classification into five quality categories. 


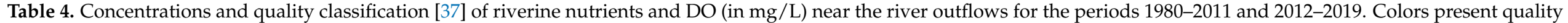

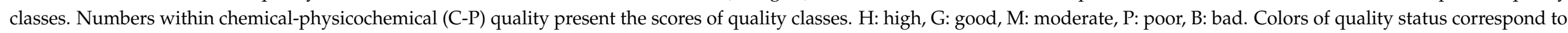
the WFD prescriptions.

\begin{tabular}{|c|c|c|c|c|c|c|c|c|c|c|c|c|c|c|}
\hline & \multicolumn{2}{|c|}{ DO } & \multicolumn{2}{|c|}{$\mathrm{N}-\mathrm{NO}_{3}$} & \multicolumn{2}{|c|}{$\mathrm{N}-\mathrm{NO}_{2}$} & \multicolumn{2}{|c|}{$\mathrm{N}-\mathrm{NH}_{4}$} & \multicolumn{2}{|c|}{$\mathrm{P}-\mathrm{PO}_{4}$} & \multicolumn{2}{|c|}{ TP } & \multicolumn{2}{|c|}{ C-P Q } \\
\hline & $\begin{array}{c}1980- \\
2011\end{array}$ & $\begin{array}{c}2012- \\
2020\end{array}$ & $\begin{array}{c}1980- \\
2011\end{array}$ & $\begin{array}{l}2012- \\
2020\end{array}$ & $\begin{array}{l}1980- \\
2011\end{array}$ & $\begin{array}{l}2012- \\
2020\end{array}$ & $\begin{array}{l}1980- \\
2011\end{array}$ & $\begin{array}{l}2012- \\
2020\end{array}$ & $\begin{array}{c}1980- \\
2011\end{array}$ & $\begin{array}{l}2012- \\
2020\end{array}$ & $\begin{array}{l}1980- \\
2011\end{array}$ & $\begin{array}{c}2012- \\
2020\end{array}$ & $\begin{array}{l}1980- \\
2011\end{array}$ & $\begin{array}{c}2012- \\
2020\end{array}$ \\
\hline Evros & 8.9 & 10.7 & 3.42 & 1.13 & 0.060 & 0.012 & 0.289 & 0.047 & 0.337 & 0.114 & 0.514 & 0.127 & 1.5 & 3.2 \\
\hline Fonias & 9.5 & 9.9 & 0.51 & 0.37 & 0.006 & 0.004 & 0.032 & 0.016 & 0.074 & 0.008 & 0.096 & 0.021 & 3.7 & 4.2 \\
\hline Nestos & 10.5 & 10.2 & 0.89 & 0.40 & 0.012 & 0.007 & 0.064 & 0.017 & 0.027 & 0.019 & 0.038 & 0.027 & 3.5 & 4.2 \\
\hline Lissos & & 9.99 & 1.99 & 1.22 & 0.009 & 0.013 & 0.106 & 0.032 & 0.032 & 0.023 & 0.041 & 0.031 & 2.7 & 3.7 \\
\hline Kompsatos & & 10.7 & 0.64 & 0.23 & 0.01 & 0.003 & 0.051 & 0.027 & 0.049 & 0.031 & 0.059 & 0.040 & 3.3 & 3.8 \\
\hline Strymon & 10.2 & 8.3 & 1.45 & 0.83 & 0.024 & 0.073 & 0.094 & 0.081 & 0.142 & 0.276 & 0.167 & 0.311 & 2.7 & 1.8 \\
\hline Axios & 9.6 & 10.4 & 2.11 & 1.44 & 0.073 & 0.030 & 0.207 & 0.055 & 0.365 & 0.201 & 0.606 & 0.217 & 1.5 & 2.7 \\
\hline Loudias & 5.5 & 6.3 & 3.19 & 1.52 & 0.064 & 0.070 & 0.634 & 0.639 & 0.092 & 0.454 & 0.346 & 0.481 & 1.7 & 1.2 \\
\hline Aliakmon & 10.4 & 10.6 & 0.93 & 1.49 & 0.065 & 0.049 & 0.096 & 0.125 & 0.021 & 0.197 & 0.090 & 0.213 & 3.2 & 2.3 \\
\hline Pinios & 10.8 & 10.3 & 2.12 & 0.98 & 0.014 & 0.016 & 0.049 & 0.088 & 0.084 & 0.089 & 0.108 & 0.106 & 3.0 & 3.2 \\
\hline Spercheios & 8.3 & 6.9 & 1.20 & 0.79 & 0.014 & 0.017 & 0.054 & 0.129 & 0.074 & 0.062 & 0.102 & 0.057 & 3.3 & 3.2 \\
\hline Aoos & 10.2 & 10.7 & 0.28 & 0.28 & 0.011 & 0.003 & 0.033 & 0.016 & 0.013 & 0.016 & 0.027 & 0.024 & 3.8 & 4.3 \\
\hline Louros & 9.8 & 9.9 & 1.41 & 0.81 & 0.006 & 0.004 & 0.066 & 0.045 & 0.014 & 0.027 & 0.029 & 0.036 & 3.5 & 3.8 \\
\hline Acheloos & 10.6 & 8.1 & 0.59 & 0.19 & 0.014 & 0.003 & 0.039 & 0.024 & 0.107 & 0.007 & 0.031 & 0.014 & 3.5 & 4.2 \\
\hline $\begin{array}{c}\text { V. } \\
\text { Kifissos }\end{array}$ & 9.2 & 9.6 & 1.66 & 3.12 & 0.023 & 0.030 & 0.164 & 0.028 & 0.028 & 0.038 & 0.036 & 0.048 & 3.3 & 3.2 \\
\hline Koiliaris & 10.2 & 10.0 & 0.52 & 0.64 & 0.003 & & 0.054 & 0.045 & 0.043 & 0.033 & 0.069 & 0.042 & 3.8 & 3.9 \\
\hline
\end{tabular}


Finally, Table 5 illustrates the average of Biological Oxygen Demand $\left(\mathrm{BOD}_{5}\right)$ levels of the examined rivers based on data of the NMP.

Table 5. Average $\mathrm{BOD}_{5}$ concertation in the examined rivers $\left(\mathrm{mg} \mathrm{O}_{2} / \mathrm{L}\right)$ according to data of the NMP (2012-2015, 2018-2019). Colors present quality classes; high $<2$, good 2 to $<4$, moderate 4 to $<7$ (strictest prescriptions depicted by the authors of [52]).

\begin{tabular}{cccccc}
\hline River & BOD $_{\mathbf{5}}$ & River & BOD $_{\mathbf{5}}$ & River & BOD $_{\mathbf{5}}$ \\
\hline Evros & 3.45 & Axios & 3.86 & Aoos & 1.50 \\
\hline Fonias & 0.60 & Loudias & 4.03 & Louros & 2.64 \\
\hline Nestos & 1.71 & Aliakmon & 2.89 & Acheloos & 3.10 \\
\hline Lissos & 1.71 & Pinios & 3.27 & Alfeios & 1.68 \\
\hline Strymon & 3.44 & Spercheios & 4.77 & Evrotas & 2.17 \\
\hline
\end{tabular}

Based on the entire dataset (1980-2020), only one river (Loudias) presented a lower than good DO quality (Table 4). In most rivers, phosphorous (both as orthophosphate and $\mathrm{TP})$ presented a higher than good quality, whereas for N-species, the vast majority of the rivers illustrated a lower than good quality, besides ammonium within the recent period (2012-2020). Considering BOD $_{5}$, most of the rivers exhibited a high-good quality, and only the Spercheios and Loudias presented moderate quality (Table 5).

By comparing the two periods (i.e., 1980-2011 and 2012-2020), it becomes apparent that 10 out of 16 rivers improved their oxygenation status. In addition, the Evros showed an improved DO quality, contrary to Strymon, Spercheios, and Acheloos, where DO quality dropped (Table 4). A general improvement within the recent period was evident for nitrogen species concentration and quality, and only a small number of rivers illustrated a degradation for particular N-species. Nitrate showed the most remarkable improvement within the recent period; 15 out of 18 rivers revealed a nitrate concentration drop, 13 an improvement, and only two (V. Kifisos and Aliakmon) a worsen in nitrate quality status. The second case of improvement concerns ammonium; 14 out of 18 rivers revealed a reduction of ammonium concentration, 9 an improvement in ammonium quality, and two (Pinios and Spercheios) a decrease in ammonium quality status. Finally, regarding nitrite 10 out of 17 rivers improved their concentration and only one river (Strymon) revealed a deterioration of nitrite quality status. As far as phosphate and TP it concerns, concentrations dropped in 10 and 12 rivers, respectively, while the quality status remained unchanged in most rivers. Only a small number of rivers showed an improvement (5 and 4 for phosphate and TP, respectively) or a degradation ( 4 and 3 for phosphate and TP, respectively) in their quality status within the recent period. The Strymon, Loudias, and Aliakmon rivers worsened their status regarding both phosphate and TP, and V. Kifissos regarding phosphate. Finally, focusing on the C-P quality of the two periods, in the recent one, 9 rivers revealed an improvement, 7 rivers retained their quality status, and in two rivers (Strymon and Aliakmon), the C-P quality status worsened.

For a comprehensive overview of long-term nutrient variations, the annual variability of nitrate and TP concentration during 1980-2020 for 16 rivers are depicted in Figure 2.

Besides the Evros, which suffered from severe nitrate contamination as early as in the mid-1980s, reaching its maxima in the early 1990s, the vast majority of the rivers presented nitrate peaks in the early 2000s (Figure 2a). During the last decade, all rivers showed lower nitrate concentrations than in the previous decades, except of V. Kifissos.

Transboundary rivers entering Greece illustrated elevated TP values during the period 1980s-end of 1990s, followed by a decline in concentrations (Figure 2b). Rivers lying entirely in Greece reached maximum TP levels between the late 1990s and early 2000s. 

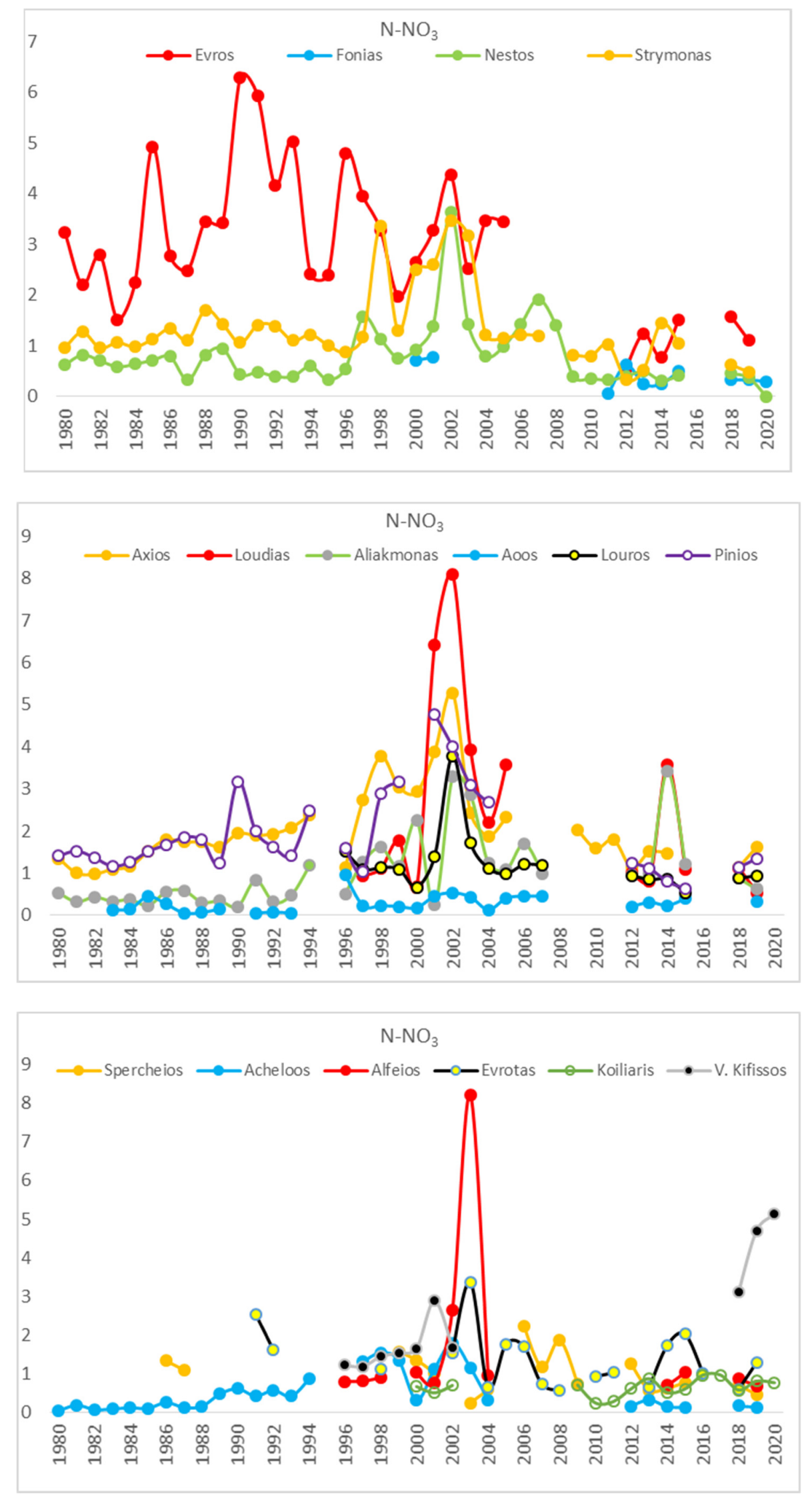

(a)

Figure 2. Cont. 

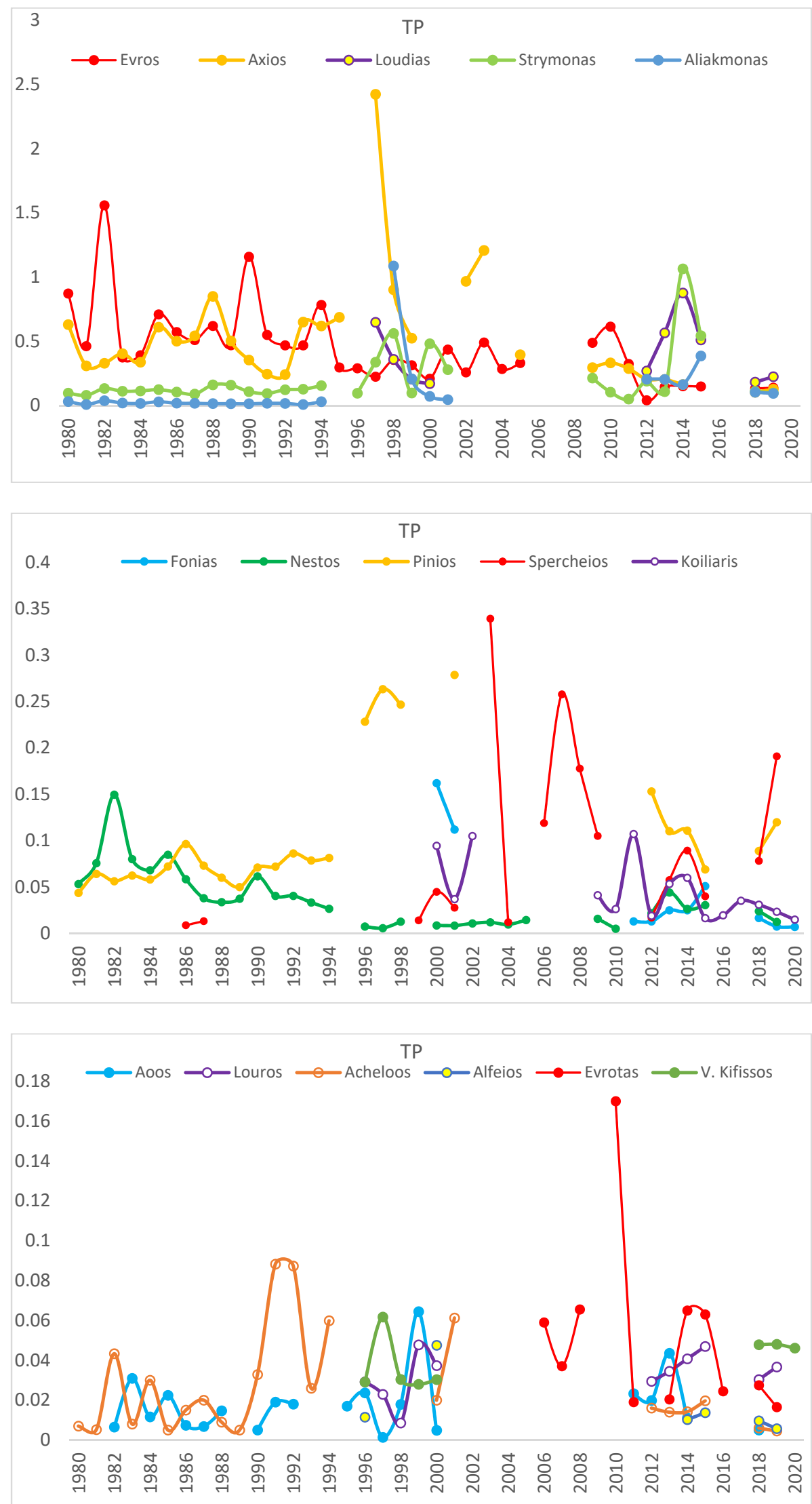

(b)

Figure 2. 40-year nitrate $\left(\mathrm{N}-\mathrm{NO}_{3}\right)$ (a) and TP (b) variation in the examined Greek rivers (in $\mathrm{mg} / \mathrm{L}$ ). 
Orthophosphate presented in general similar interannual trends with TP. Ammonium showed a long-term decrease in the Evros, Nestos, Aoos, Acheloos, Louros V. Kifissos, and Alfeios. The Axios revealed maximum ammonium levels at the end of the 1990's, then a decrease. A long-term ammonium diminishing in the Strymon, Pinios, and Aliakmon has been interrupted by recent increases. The other rivers (Loudias, Spercheios, Evrotas, Koiliaris, and Fonias) do not show clear temporal trends.

A number of rivers, such as the Evros, Nestos, Strymon, Axios, Pinios, Aliakmon, and Acheloos, revealed nitrate and/or phosphorous peaks during the 1988-91 drought period. Within this period, numerous rivers presented low flow and even large ones desiccated in certain reaches, thus being affected by a "concentration" effect [11] (Figure 3). On the contrary, years 2001-2003 were characterized by rainy autumns with floods [53], that caused nitrate leaching from agricultural land (Figure 3).

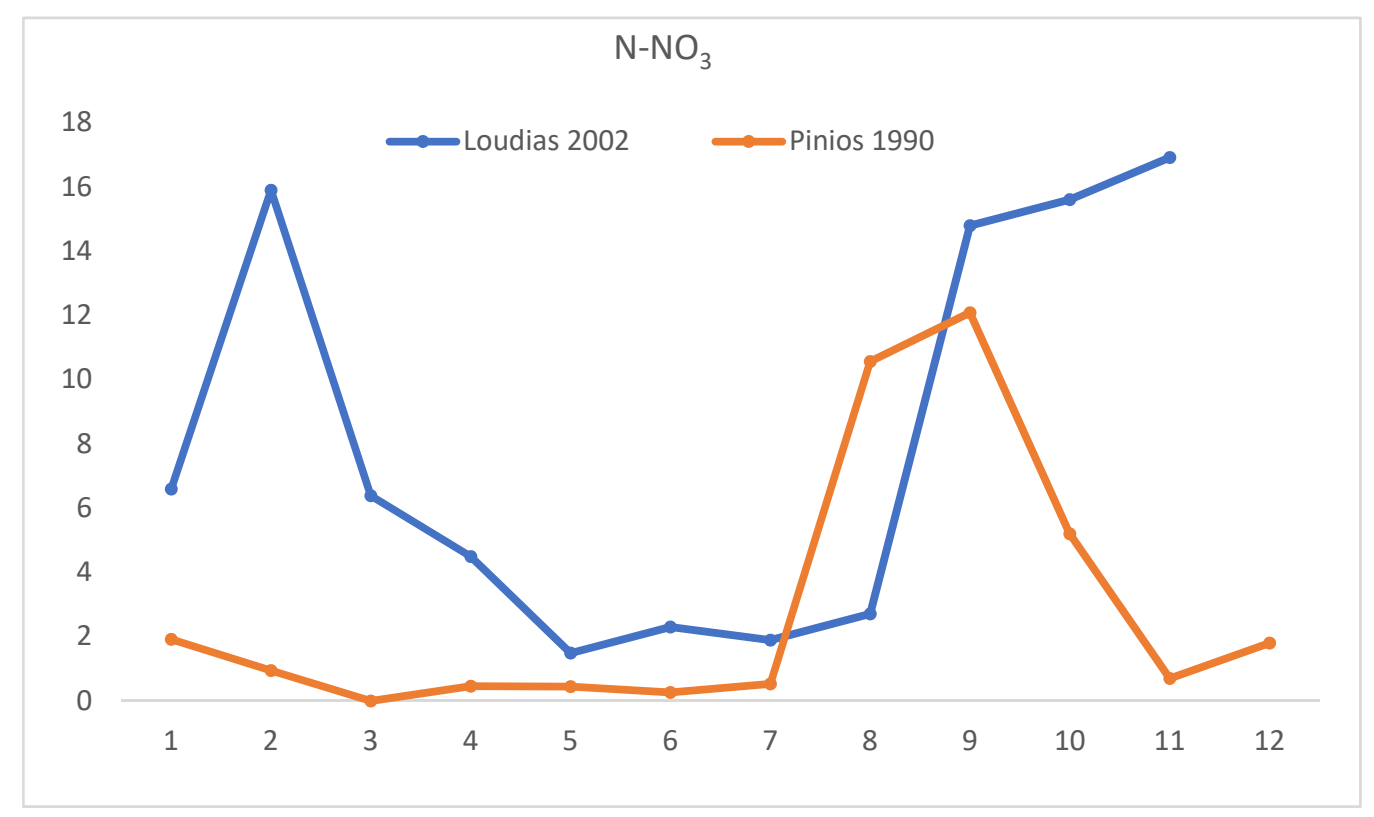

Figure 3. Monthly nitrate $\left(\mathrm{N}-\mathrm{NO}_{3}, \mathrm{mg} / \mathrm{L}\right)$ variation in the Loudias and Pinios rivers during hydrologically distinct years.

Within the period 1980-2018, there is a consistent drop of $\mathrm{N}$ and $\mathrm{P}$ fertilizer quantities use in Greece (Figure 4), along with a gradual increase of arable land area $\left(154 \mathrm{~km}^{2} /\right.$ year, reaching 35\% of the country's area in 2018). However, even with the financial crisis and the respective gross domestic product (GDP) drop, slight increasing trends of fertilizer application from 2010 onwards are also evident (Figure 4 [54,55]). In Bulgaria, with the highest arable land area (69.2\% of the country's area in 2018), significant $\mathrm{N}$ and $\mathrm{P}$ fertilizer quantities application from the beginning to mid-end 1980s, was followed by a dramatic decline up to the end of $1990^{\prime}$ s, and then by a general increase, which was however not as high as the initial levels, especially for P. In North Macedonia, the application of fertilizers quantities is low, while a long-term decrease of the arable land area is apparent (the arable land portion in 2018 was 33\% of the country's area) (data [54]). Regarding livestock, the diminishing number of animals is evident for Bulgaria during 1980-2018 (data [54]) and Greece within the period 2004-2015 [56-58].

Regarding the application of fertilizers per unit area, in 2018, for example, Bulgaria applied similar quantities $\left(92.1 \mathrm{~N} \mathrm{~kg} / \mathrm{ha}\right.$ and $19.2 \mathrm{P}_{2} \mathrm{O}_{5} \mathrm{~kg} / \mathrm{ha}$ ) as to the European Union average (90 N kg/ha and $\left.21.8 \mathrm{P}_{2} \mathrm{O}_{5} \mathrm{~kg} / \mathrm{ha}\right)$; Greece applied fewer quantities $(55.7 \mathrm{~N} \mathrm{~kg} / \mathrm{ha}$ and $18.4 \mathrm{P}_{2} \mathrm{O}_{5} \mathrm{~kg} / \mathrm{ha}$ ), while North Macedonia used lesser quantities ( $39 \mathrm{~N} \mathrm{~kg} / \mathrm{ha}$ and 9.0 $\mathrm{P}_{2} \mathrm{O}_{5} \mathrm{~kg} / \mathrm{ha}$ ) [54]. 


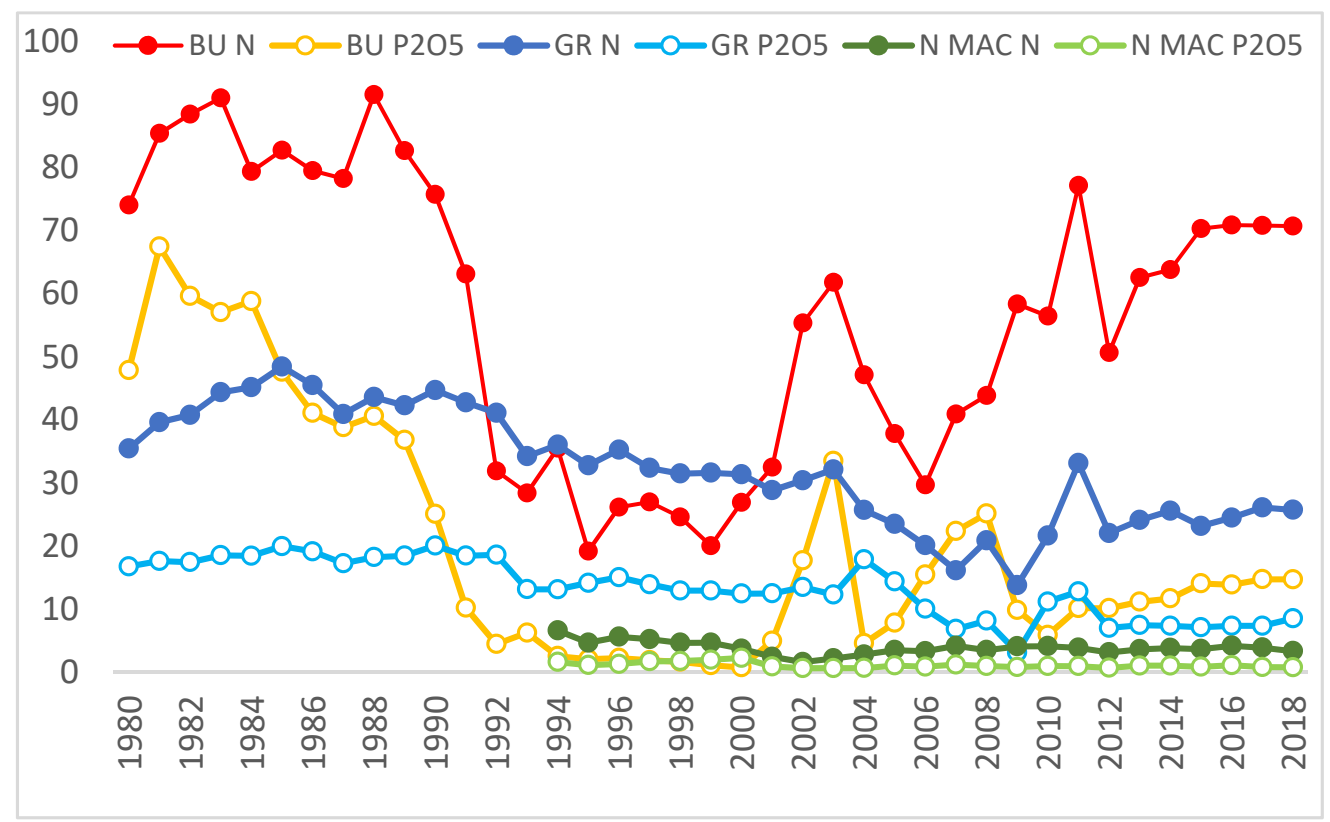

Figure 4. Total nitrogen $(\mathrm{N})$ and phosphorous $\left(\mathrm{P}_{2} \mathrm{O}_{5}\right)$ fertilizer application $(\mathrm{t} / \mathrm{yr})$ in Greece, Bulgaria, and North Macedonia during 1980-2018 (data [54]).

\section{Discussion}

\subsection{River Quality Status}

According to the data of the second RBMPs (based on the first monitoring round, i.e., 2012-2015, Greece presents a higher percentage of water bodies above moderate ES (68.2\%) than the EU as a whole (43.9\%). In addition, the mean nitrate concentration of Greek rivers $\left(1.1 \mathrm{mg} / \mathrm{L} \mathrm{N}-\mathrm{NO}_{3}\right)$ is half of the mean nitrate concentration $\left(2.2 \mathrm{mg} / \mathrm{L} \mathrm{N}-\mathrm{NO}_{3}\right)$ found in European rivers, counter to phosphate (mean phosphate in Greek and European rivers is $120 \mu \mathrm{g} / \mathrm{L}$ and $78.8 \mu \mathrm{g} / \mathrm{L}$, respectively) [14]. According to the analyzed data, the average $\mathrm{BOD}_{5}$ in Greek rivers $(2.7 \mathrm{mg} \mathrm{O} / \mathrm{L})$ slightly exceeds the European average $\left(2.1 \mathrm{mg} \mathrm{O}_{2} / \mathrm{L}\right.$; ref. [52]).

On the contrary, focusing on the examined rivers, most of them (15 out of 18), revealed a lower than good ES (Table 2). This figure is not surprising if we consider that these rivers are heavily affected by anthropogenic impacts. In addition, the examined stations are located at their downstream reaches, thus being accumulatively subjected to multipressures from the entire basins.

Within the time frame of existing ES data (maximum eight years), it was not possible to detect any consistent inter-annual trends for most of the rivers examined. Thus, to draw safe results on ES temporal trends, additional annual data should be considered in the future.

On the contrary, within the period of up to 40 years of observations, nutrient concentration decreasing trends are obvious (Table 4, Figure 2). Correlation analysis showed significant correlations among nutrient species, particularly during the recent period, where chemical analyses were performed by the same laboratory. The drop of nutrient concentrations and the improvement of C-P quality in most of the rivers are partly attributed to the long-term reduction of fertilizer application in the adjacent countries. In North Macedonia, where the Axios originates, the main reason for this reduction is the gradual decrease of arable land area and the management of fertilizer industry outflows [16]. For Bulgaria, aside from fertilizer use reduction, livestock diminishing may have also contributed to this enhancement.

In certain basins, riverine nitrate quality may have been additionally improved, due to measures related to applying the Nitrates Directive (91/676/EEC). As nitrate vulnerable 
zones have been classified the Thessaly plain (drained by Pinios R.), the north and south Evros R. sections, the Strymon basin, the plain of Thessaloniki-Pella-Hemathia drained by the downstream portions of Axios, Loudias, and Aliakmon, and the Spercheios R. According to the authors of [56], the case of Thessaly plain comprised a positive example for implementing the Nitrates Directive. An action plan aimed to reduce nitrogen fertilizer application through a set of measures, including better effectiveness of $\mathrm{N}$ use, the introduction of new irrigation techniques, and the cultivation of suitable crop varieties. It has been estimated that during 1996-2000, a reduction of the applied N fertilizers of about 25-30\% has occurred [56].

Another reason for the recent improvement of riverine nutrient quality status is the installation and upgrading of urban and industrial WWTP infrastructure in the three countries (Greece, Bulgaria, and North Macedonia). For the management of municipal wastewaters, Greece follows the Directives 91/271/EC and 98/15/EC. At the beginning of the 1990s, the construction of UWWTPs started to increase rapidly, and in 2005 around $70 \%$ of the population was served, mainly by primary treatment. From 2010 onwards, the situation improved substantially, and in 2012, over $85 \%$ of the population was served, $80 \%$ of which by tertiary treatment [40]. In Bulgaria, where one of the most significant pressures on rivers is point source pollution from UWWTPs (by $22 \%$ ), appropriate infrastructure is gradually implemented to comply with the Wastewater Treatment Directive [59].

However, even today in Greece, there is a high number of mainly medium agglomerations (5000-10,000 inhabitants) and some of more than 15,000 inhabitants not yet acquiring urban wastewater treatment [40]. In addition, there are settlements attaining sewerage systems that discharge untreated wastewater into receiving surface waters. Even more, there are evidence of poorly functioning UWWTPs [60,61], and thus, the current challenge lies in their efficient operation, as the Programs of Measures (PoMs) of the RBMPs highlight. In Bulgaria, only close to $26 \%$ of wastewater is collected, of which $27 \%$ is being treated [59]. Finally, in North Macedonia, about $24 \%$ of settlements have access to wastewater treatment [62].

A number of rivers present deterioration in their quality status for certain nutrients within the recent period, as a result of inadequately operating WWTPs, untreated municipal effluents, untreated agro-industrial wastewaters, and diffuse pollution from agriculture; V. Kifissos (nitrate and phosphate), Loudias (phosphate and TP), Pinios and Sperchios (ammonium), whereas in Strymon a deterioration of the C-P quality is evident. It should be noted that the worsening of the C-P quality in Aliakmon within the recent period, is due to the fact that the NMP station in the recent period is located downstream, which is impacted by pollution, whereas that of the old time series was located far upstream.

Riverine nutrient pollution is not alone the result of the impact of pressures, such as agricultural runoffs and untreated or partly treated municipal and industrial wastewater discharges. It largely depends on hydrological factors, such as the volume of river water available (causing dilution or concentration of solutes), flood events (causing agricultural land flashing), and droughts (causing increased groundwater contribution to river flow and evaporation) [14]. For example, during the 1988-1991 drought period and in the climatically peculiar 2001-2003 years, rivers presented severe nitrate concentrations (Figure 3). Thus, to interpret long-term trends, extreme annual hydro-meteorological events should be taken into consideration.

In the following, we address rivers showing a lower than good ES and propose measures, related to the degradation of specific BQEs, complementary to those prescribed in the second RBMPs.

Despite the recent improvement of the C-P quality in the Evros, its ES remains bad. Thus, additional efforts should be devoted to point source pollution, particularly in Bulgaria and Turkey, where sewage and industrial effluents still create major pollution problems $[3,16,63]$. In the Nestos, hydromorphological alterations downstream the reservoirs adversely affect fish assemblages. The RBMP recognizes the impacts of the hydroelectric dams and recommends abatement measures, not mentioning, however, the need to 
implement site-specific ecological flows. The poor ES of the Lissos is also due to hydromorphological alterations, as fish and macrophyte metrics indicate. This may be partly faced through riparian forest restoration actions, anticipated in the respective RBMP. In the Kompsatos, measures to improve poor ES should target treatment of urban wastewater and livestock farm effluents, along with sand and silt mining control. In the Strymon, the RBMP recognizes the impact of diffuse pollution at the downstream portion of the river, but no related measures have been prescribed. Since the river is included in the Nitrates Directive, best agricultural practices should be ensured, along with the construction of WWTPs and the control of existing ones. An improvement of the C-P quality of the Axios in recent years was not enough to reverse poor ES, resulting from macroinvertebrate and diatom metrics, indicating impacts from point source pollution, along with hydromorphological alterations that disturb fish communities. No related concrete measures are included in the RBMP. Classified as an artificial water body, the Loudias shows alarming impacts of pollution and hydromorphological alterations (Tables 2-5). Despite severe hydromorphological alterations of the Aliakmon, downstream of a series of reservoirs (as fish metrics indicate), the downstream portion of the river is subject to the effluents of agrochemicals and treated and untreated urban and agro-industrial wastewaters. These need to be addressed, together with applying site-specific ecological flows. In the Pinios, the recent improvement of nitrate concentrations may be due to implementing the Nitrates Directive in the Thessaly basin, while the increase of ammonium and the relatively high $\mathrm{BOD}_{5}$ levels may result from inadequately operating urban and industrial WWTPs that should be addressed. Moreover, water abstraction and flood control cause hydromorphological alterations, as poor fish quality indicate. Since the hydrological budget of the basin is strongly negative, PoMs mainly target water management issues. In the Sperchios, point sources of pollution, particularly at the downstream portion of the river, should be mitigated in line with the RBMP. In the Louros, the deterioration of fish and aquatic macrophyte quality point out towards hydromorphological restoration. Similarly, the Acheloos lower section (downstream the reservoirs) should be hydromorphologically restored. The RBMP anticipates the banning of sand abstraction, the main issue, however, remains the maintenance of ecological flows. The V. Kifissos discharges into lake Yliki, which is a potable water reserve for the greater Athens area. The river presents a good ES. However, the NMP station lies upstream of an extended agricultural plain with agro-industrial units. Several agglomerations are currently not served by urban WWTPs, and thus, PoMs target the management of point source pollution. Along with the displacement of the NMP station close to the inflow to Yliki L., measures should additionally target diffuse pollution. In the Alfeios, besides the need to improve UWWTP infrastructure, hydromorphological alterations should be addressed; the prohibition of gravel extraction alone, as anticipated in the RBMP, may not be enough to improve fish metrics. In the Evrotas, the ES largely depends on the operation efficiency of the UWWTP of Sparta, drought events, and artificial desiccation. PoMs include strict restriction of water, gravel, and sand abstraction and control of agro-industrial effluents. Regular controls of the operation efficiency of the WWTPs and the construction of fish refuges to maintain endemic species during droughts are additionally needed.

\subsection{Strengths and Weaknesses of the WFD Implementation in Greece}

\subsubsection{Administrative Issues and Proposals}

Greece has been traditionally characterized by a hierarchical and centralized political and administrative structure and a weak civil society with a traditionally low rate of participation in various consultation processes $[64,65]$. Water governance has been considered weak, with limited participation, decentralization, democratic decision making, networking, and integrative approaches, nevertheless, showing trends towards a more effective reform [66]. This has led to an environment that is particularly unfriendly to the introduction of substantial participatory arrangements as required by implementing the WFD $[65,67]$. As a result, interested parties, even the stakeholders of the Greek WDS, had a restricted involvement in the process, and RBMPs have been merely established by a 
top-down approach, although it has been organized to work vice-versa. In fact, there was no continuous active involvement of stakeholders and the general public in developing the initial RBMPs [10]. This figure has not been substantially changed during implementing the second round of the RBMPs.

As a result of difficulties facing the administration both at the central and regional level, RBMPs are still implemented centrally by external consultant companies. Thus, the WD's administration should be ensured to embed long-term capacity and expertise building, guaranteeing the decentralization of the implementation process, while appropriate participation of the public, will connect the planning process with the water management reality [10]. We additionally suggest the reinforcement of the NCW to ensure the incorporation of the best available knowledge on the status of the environment, its management, and conservation priorities within the RBMPs.

The RBMPs contain long lists of PoMs. Basic measures are horizontal measures required for implementing EC legislation on water protection and those arising from the obligation to implement the WFD, including administrative measures and preparation of general technical specifications, e.g., for wastewater reuse, water metering, and ecological flows, and promotion of water-saving and organic farming through subsides. Supplementary measures include RB-specific measures, such as emission controls, reconstruction, and restoration of wetland areas, water over-pumping control, promotion of adapted agricultural production, irrigation water-saving techniques, construction of desalination plants, artificial aquifer replenishment, etc. For the next RBMPs, specific measures should be connected to particular pressures, following the indications of ecological and chemical status assessments, and where the causes/effects relationships are unclear specific research should be applied.

Although PoMs target water metering, there is still a lack of its implementation in agriculture, which is however not only a Greek problem [68]. Irrigation water must be metered, and pricing policies should be applied considering the importance of agriculture for the country's GDP [55]. Socially fair water pricing is an important aspect during the water pricing policies determination [69]. Moreover, no specific additional measures in areas designated for protecting habitats or species are part of the PoMs either in the first RBMPs [10] nor in their update. Finally, the main concern regarding PoMs is the lack of prioritization of measures, which needs to be addressed through special methodological approaches [70,71].

\subsubsection{Technical Issues and Proposals}

Despite the efforts of the MEE that are reflected in the progress of the updated RBMPs, such as development and application of methodologies regarding anthropogenic pressures and impacts, assessment of surface water status, hydromorphological alterations, heavily modified and artificial WBs, and exemptions, a number of actions should be considered to overcome current weaknesses. We hereby present a (not exhaustive) list of cases and suggestions.

The design of the NMP network was based on the most updated knowledge of the state of aquatic ecosystems. However, given the lack of studies on a national level regarding the state of the aquatic environment (even pressure-based ones) prior to the WFD implementation, the initial design included a number of drawbacks, which have been only partly faced in the second monitoring round. The current monitoring network includes a total of 490 river stations (195 operational, 290 surveillance, and one investigative), showing only $8 \%$ increase compared to the initial network. The density of the surface water network is three samples per $1000 \mathrm{~km}^{2}$. Given the high biogeographical diversity of the country and the numerous highly fragmented unique fluvial ecosystems, this number is considered low. To compare, Germany has a river station density of 38 per $1000 \mathrm{~km}^{2}$ [72]. Since Greece identified 1345 river WBs, there are WBs where monitoring stations are missing. To overcome this problem, WBs with missing stations were grouped together with WBs with existing stations. However, this approach is far from the principles of the Directive. 
In certain WDs, such as the Aegean Islands WD (EL 14), there are only 10 stream water stations designated. According to the respective RBMP, this will be faced in the third round of RBMPs. In addition, predominately perennial streams of the 4th order and above were initially included in the first monitoring round [10]. Given the fact that non-perennial river basins roughly cover $40 \%$ of the countries' surface area, and considering their importance in ecosystem services [73], it is essential to increase the number of intermittent rivers and streams in the national monitoring network. For the ecological assessment of intermittent rivers, however, special approaches should be developed [74]. Concluding, there is a need to enhance the river monitoring network to safeguard stations for all WBs, include a higher number of non-perennial rivers, and capture small, but ecologically significant streams, e.g., on the islands.

The existing hydrological network belongs to various state authorities (PPC, MEE, MRDF) and is mostly degraded and inactive [75]. The monthly hydrological monitoring efforts of the National Monitoring Program are not sufficient for sound integrated water resources management on a river basin scale, as has been shown in the case of Samothraki Island [76]. The estimation of patterns leading to flash floods and the capability of properly predicting and intercepting social and environmental impacts from these events, makes the need for continuous data collection imperative. This is also true for the dry period of the year where river parts may desiccate because of excess irrigation water use, thus, threatening river integrity and biodiversity. Moreover, the results of applying river basin water balance models remain questionable, due to a lack of reliable model input data [77]. To assess model-based reliable water balances and develop appropriate water resources management plans, there is an urgent need to re-design and maintain hydrological monitoring networks and collect appropriate environmental model input data, under a single management authority.

Contrary to the initial RBMPs, in their first update, WBs have been assigned to ecological classes using appropriate assessment and classification systems of hydromorphological, C-P, and BQEs. These systems were largely developed by the members of the NCW; a nutrient classification system [37] and metrics for the classification of BQ using macroinvertebrates [32,33], phytobenthos [34], and fish [36]. In the future, classification systems for intermittent rivers and streams should be developed and applied.

As far as pressure and impacts analysis it concerns, the methodology set [78] and the updated RBMPs do not consider information on pesticide usage and assessment of other hazardous substances regarding diffuse pollution pressures, contrary to the related Guidance Document [79]. In some cases, pressure and impacts analysis is not presented transparently enough. For example, the streams' pollution loads of the islands Thasos and Samothraki (EL 12) are treated as if the streams of both islands belong to a common basin.

In addition, it seems that there is a significant underestimation of hydromorphological pressures and impacts on surface WBs [80]. In fact, if we compare the percentage of pressure types for surface waters between Greece and the European average in the updates of the Greek RBMPs, hydromorpgological pressures unrealistically comprise only $8 \%$ compared to a 34\% European average, whereas hydromorphological impacts in the Greek RBMPs cover only $13 \%$ compared to a European average of $43 \%$ [42]. Hydromorphological elements are not crucial for ES assessment, but are largely causing the failure to achieve good ES [81]. The underestimation of hydromorphological pressures in Greek RBMPs is reflected in the limited measures included in PoMs regarding restoration of hydromorphological alterations, which hinders the enhancement of ecosystem services [80]. Future PoMs should target, besides maintaining ecological flows and levels (by conducting site-specific studies), safeguarding site-specific habitat connectivity, mitigation of deltaic and coastal areas from erosion (due to sediment retention in reservoirs), restoring riparian vegetation, water courses (e.g., remeandering), floodplains and wetlands, constructing fish ladders and creating habitats for aquatic biodiversity conservation, etc. Particularly, natural water retention measures are considered urgent and important, since they will contribute to reduced flood and drought risk, improvement of ecosystem functions and ES, and will also 
apply for the need and commitment of halting and reversing the loss of aquatic biodiversity [80]. In addition, natural water retention measures will contribute to the enhancement of surface-groundwater interactions, groundwater recharge, and improvement of water balances, and will ensure additional water resources for agriculture. Besides substantial ecological benefits, restoring and recreating natural retention areas (i.e., floodplains) across rivers and streams in Greece has a Benefit Cost Ratio of 2.5 EUR compared to 1.1 EUR for "grey" infrastructure solutions, such as creating and strengthening dyke systems [82]. We furthermore propose the preparation of a national guidance document on ecological lake level fluctuations (as it is foreseen for ecological flows), since this is anticipated to be implemented at RB-level despite the fact that respective guidance at a national level is currently lacking. Finally, it is essential to include currently missing urban stream upgrade and restoration in the PoMs [80].

A more efficient implementation of the Nitrates Directive is also essential to further reduce nitrates in surface and groundwaters. In addition, phosphorus control measures are also important to be implemented. Finally, in our opinion, the NMP sampling efforts may not be sufficient to capture chemical pollution, and in certain cases, there is a need to include river sediments in the assessment procedure.

\section{Conclusions}

The rivers and their reaches selected for this study largely comprise the most degraded ones in Greece. It is thus not surprising that poor ES predominates. Point source pollution remains one of the main pressures on the examined rivers, adversely affecting their ES. However, the overall decrease of ammonium and nitrite concentrations within the recent period, and the relatively low $\mathrm{BOD}_{5}$ levels, indicate a general improvement of WWTP infrastructure. Moreover, diffuse pollution from agricultural sources reveals diminishing trends as the substantial overall drop in nitrate concentrations within the recent period indicates. This is due to long-term fertilizer application drop in Greece, Bulgaria, and North Macedonia, and possibly, to the application of the Nitrates Directive. The recent improvement of the C-P quality of a number of rivers, such as Evros, Nestos, Axios, Lissos, Pinios, Acheloos, and Aoos, are positive examples related to decreased fertilizer application together with efforts in building infrastructure for UWWT in riparian cities. Further advancements in these issues, in combination with strict control of the efficiency of existing urban and industrial WWTPs, will certainly contribute to the enhancement of the rivers' ES. Moreover, hydromorphological pressures and restoration of ecosystem services, considering natural water retention measures and nature-based solutions, need to be addressed, as a number of rivers reveal a degradation of habitats reflected in fish and macrophyte metrics status.

In relation to the pre-Directive poor national environmental management and conservation practices, the RBMPs and related PoMs are a significant step forward. However, it seems that overall, the RBMPs are mostly implemented mechanistically, more to satisfy the Directive's requirements than to introduce a real change of attitudes towards sustainable water and land management and environmental conservation. This is mirrored in the central implementation of RBMPs, weak connection between RBMPs and public participation, and limited interrelation between PoMs and ecosystem services. The forthcoming RBMPs are a great challenge for the Greek water authorities to change attitudes and overcome historical weaknesses related to structural and organizational shortcomings. Rationalization and modernization of competent authorities, decentralization of the implementation procedure, and opening the procedure to local stakeholders and the general public are among the most important issues to be faced.

Author Contributions: Conceptualization N.T.S.; Structure Design N.T.S. and Y.A.; Data Provision N.T.S. and M.L., Data Analysis N.T.S. and I.K.; Writing-Original Draft Preparation, N.T.S.; WritingReview and Editing, N.T.S., M.L., Y.A. and I.K. All authors have read and agreed to the published version of the manuscript. 
Funding: This research received no external funding.

Institutional Review Board Statement: Not applicable.

Informed Consent Statement: Not applicable.

Data Availability Statement: Data of this study may be found in the websites of the Ministry of Rural Development (http:/ / www.minagric.gr/index.php/el/for-farmer-2/450-greek-content/ eggeiesbeltioseis/sxedismowee/potamia (accessed on 1 July 2021)) and WISE database (https:/ / www.eea.europa.eu/data-and-maps/dashboards/wise-wfd (accessed on 1 July 2021)). Data from the Ministry of Environment and Energy are not available in the Ministry's website.

Acknowledgments: The authors of this article wish to thank Aggeliki Mentzafou for creating Figure 1 and offering data for Table 1.

Conflicts of Interest: The authors declare no conflict of interest.

\section{References}

1. Voulvoulis, N.; Arpon, K.-D.; Giakoumis, T. The EU Water Framework Directive: From great expectations to problems with implementation. Sci. Total Environ. 2017, 575, 358-366. [CrossRef] [PubMed]

2. EC. Fitness Check of the Water Framework Directive, Groundwater Directive, Environmental Quality Standards Directive and Floods Directive; European Commission: Brussels, Belgium, 2019.

3. Skoulikidis, N.; Economou, A.; Gritzalis, K.; Zogaris, S. Rivers of the balkans. In Rivers of Europe, 1st ed.; Tockner, K., Uehlinger, U., Robinson, C.T., Eds.; Academic Press: Cambridge, MA, USA; Elsevier: Amsterdam, The Netherlands, 2009; pp. 421-466. ISBN 9780080919089.

4. Prieto, M.M. Facing the challenges of implementing the European Water Directive in Spain. In Water Policy in Spain, 1st ed.; Garrido, A., Llamas, M.R., Eds.; CRC Press: Boca Raton, FL, USA; Taylor \& Francis Group: Boca Raton, FL, USA, 2009; pp. 175-184. ISBN 9781138114432.

5. Carvalho, L.; Mackay, E.B.; Cardoso, A.-C.; Baattrup-Pedersen, A.; Birk, S.; Blackstock, K.L.; Borics, G.; Borja, A.; Feld, C.K.; Ferreira, M.-T.; et al. Protecting and restoring Europe's waters: An analysis of the future development needs of the Water Framework Directive. Sci. Total Environ. 2019, 658, 1228-1238. [CrossRef] [PubMed]

6. Lekakis, J.N. Environmental management in Greece and the challenge of sustainable development. Environmentalist 1995, 15, 16-26. [CrossRef]

7. Kati, V.; Kassara, C.; Psaralexi, M.; Tzortzakaki, O.; Petridou, M.; Galani, A.; Hoffmann, M.T. Conservation policy under a roadless perspective: Minimizing fragmentation in Greece. Biol. Conserv. 2020, 252, 108828. [CrossRef]

8. HCMR. Monitoring of the Ecological Water Quality of Rivers, Coastal and Transitional Waters of Greece to Implement the Article 8 of Water Framework Directive 2000/60/EC; Ministry of Environment and Energy, Special Secretariat of Water: Attica, Greece, 2016.

9. Economou, A.; Skoulikidis, N. Reference Conditions and Classification of the Country's Inland Waters according to the WFD. In Proceedings of the WFD-Harmonization with the Greek Reality Conference, Athens, Greece, 21 May 2002.

10. EC. Report on the Implementation of the Water Framework Directive River Basin Management Plans; Member State: Greece; European Commission: Brussels, Belgium, 2015.

11. Skoulikidis, N.T.; Bertahas, I.; Koussouris, T. The environmental state of freshwater resources in Greece (rivers and lakes). Environ. Geol. 1998, 36, 1-17. [CrossRef]

12. Ovezikoglou, V.; Ladakis, M.; Dassenakis, M.; Skoullos, M. Nitrogen, phosphorus and organic carbon in main rivers of the western Greece. Glob. Nest 2003, 5, 147-156.

13. Skoulikidis, N.T.; Amaxidis, Y.; Bertahas, I.; Laschou, S.; Gritzalis, K. Analysis of factors driving stream water composition and synthesis of management tools-A case study on small/medium Greek catchments. Sci. Total Environ. 2006, 362, $205-241$. [CrossRef]

14. Skoulikidis, N. The State and Origin of River Water Composition in Greece. In The Rivers of Greece, 1st ed.; Skoulikidis, N., Dimitriou, E., Karaouzas, I., Eds.; Springer: Berlin/Heidelberg, Germany, 2018; pp. 97-128. ISBN 978-3-662-55369-5. [CrossRef]

15. Stefanidis, K.; Christopoulou, A.; Poulos, S.; Dassenakis, E.; Dimitriou, E. Nitrogen and Phosphorus Loads in Greek Rivers: Implications for Management in Compliance with the Water Framework Directive. Water 2020, 12, 1531. [CrossRef]

16. Skoulikidis, N.; Zogaris, S.; Karaouzas, Y. Rivers of the Balkans. In Rivers of Europe, 2nd ed.; Tockner, K., Zarfl, C., Robinson, C.T., Eds.; Academic Press: Cambridge, MA, USA; Elsevier: Amsterdam, The Netherlands, 2021; in press; ISBN 9780081026120.

17. Lekkas, T.; Kolokythas, G.; Nikolaou, A.; Kostopoulou, M.; Kotrikla, A.; Gatidou, G.; Thomaidis, N.S.; Golfinopoulos, S.; Makri, C.; Babos, D.; et al. Evaluation of the pollution of the surface waters of Greece from the priority compounds of List II, 76/464/EEC Directive, and other toxic compounds. Environ. Int. 2004, 30, 995-1007. [CrossRef]

18. Konstantinou, I.K.; Hella, D.; Albanis, T.A. The status of pesticide pollution in surface waters (rivers and lakes) of Greece. Part I. Review on occurrence and levels. Environ. Pollut. 2006, 141, 555-570. [CrossRef] 
19. Lambropoulou, D.; Hela, D.; Koltsakidou, A.; Konstantinou, I. Overview of the Pesticide Residues in Greek Rivers: Occurrence and Environmental Risk Assessment. In The Rivers of Greece, 1st ed.; Skoulikidis, N., Dimitriou, E., Karaouzas, I., Eds.; Springer: Berlin/Heidelberg, Germany, 2018; pp. 205-240. ISBN 978-3-662-55369-5. [CrossRef]

20. Karaouzas, I.; Kapetanaki, N.; Mentzafou, A.; Kanellopoulos, T.D.; Skoulikidis, N. Heavy metal contamination status in Greek surface waters: A review with application and evaluation of pollution indices. Chemosphere 2021, 263, 128192. [CrossRef] [PubMed]

21. Skoulikidis, N.T.; Gritzalis, K.C.; Kouvarda, T.; Buffagni, A. The Development of an Ecological Quality Assessment and Classification System for Greek Running Waters Based on Benthic Macroinvertebrates. In Integrated Assessment of Running Waters in Europe; Hering, D., Verdonschot, P.F.M., Moog, O., Sandin, L., Eds.; Developments in Hydrobiology; Springer: Dordrecht, The Netherlands, 2004; Volume 516, pp. 149-160. ISBN 978-94-007-0993-5.

22. Artemiadou, V.; Lazaridou, M. Evaluation Score and Interpretation Index of the ecological quality of running waters in Central and Northern Hellas. Environ. Monit. Assess. 2005, 110, 1-40. [CrossRef] [PubMed]

23. OECD. Environmental Performance Reviews: Greece. 2020. Available online: https://www.oecd-ilibrary.org/sites/cec20289-en/ 1/3/1/index.html?itemId=/content/publication/cec20289-en\&_csp_=f78b6fdf8ec3ba726ca305d6c10debcf\&itemIGO=oecd\& itemContentType=book (accessed on 10 January 2021).

24. United States Geological Survey (USGS). Shuttle Radar Topography Mission (SRTM) 1 Arc-Second Global. Available online: https:/ / www.usgs.gov/centers/eros/science/usgs-eros-archive-digital-elevation-shuttle-radar-topography-mission-srtm1-arc?qt-science_center_objectsO0\#qt-science_center_objects (accessed on 18 July 2019). [CrossRef]

25. Donnelly, C.; Andersson, J.C.M.; Arheimer, B. Using flow signatures and catchment similarities to evaluate a multi-basin model (E-HYPE) across Europe. Hydrol. Sci. J. 2016, 61, 255-273. [CrossRef]

26. Fick, S.E.; Hijmans, R.J. WorldClim 2: New $1 \mathrm{~km}$ spatial resolution climate surfaces for global land areas. Int. J. Climatol. 2017, 37, 4302-4315. [CrossRef]

27. BGR; UNESCO (Eds.) International Hydrogeological Map of Europe 1:1,500,000 (IHME1500). Digital Map Data v1.2, 2019, Hannover/Paris. Available online: https:// www.bgr.bund.de/EN/Themen/Wasser/Projekte/laufend/Beratung/Ihme1500/ ihme1500_projektbeschr_en.html (accessed on 18 July 2019).

28. EEA. Copernicus Land Monitoring Service 2018. CORINE Land Cover CLC2018 Version 2020_20u1. European Environmental Agency: Copenhagen, Denmark. Available online: https://land.copernicus.eu/pan-european/corine-land-cover/clc2018 (accessed on 5 May 2020).

29. Mentzafou, A.; Panagopoulos, Y.; Dimitriou, E. Designing the National Network for Automatic Monitoring of Water Quality Parameters in Greece. Water 2019, 11, 1310. [CrossRef]

30. Center for International Earth Science Information Network (CIESIN). Columbia University. 2018. Documentation for the Gridded Population of the World. Version 4 (GPWv4). Revision 11 Data Sets. Palisades NY: NASA Socioeconomic Data and Applications Center (SEDAC). Available online: https://sedac.ciesin.columbia.edu/data/collection/gpw-v4/documentation (accessed on 20 December 2019).

31. Kummu, M.; Taka, M.; Guillaume, J.H.A. Data from: Gridded Global Datasets for Gross Domestic Product and Human Development Index over 1990-2015, Dataset, 2019. Available online: https: / / research.aalto.fi/en/datasets/data-from-griddedglobal-datasets-for-gross-domestic-product-and- (accessed on 5 May 2020).

32. Lazaridou, M.; Ntislidou, C.; Karaouzas, I.; Skoulikidis, N. Harmonisation of a new assessment method for estimating the ecological quality status of Greek running waters. Ecol. Indic. 2018, 84, 683-694. [CrossRef]

33. Lazaridou, M.; Ntislidou, C.; Karaouzas, I.; Skoulikidis, N.; Birk, S. Harmonization of the assessment method for classifying the ecological quality status of very large Greek rivers Knowl. Manag. Aquat. Ecosyst. 2018, 419, 50. [CrossRef]

34. Smeti, E.; Karaouzas, I. Defining New Classification Boundaries for the Ecological Status Assessment of Rivers in Greece, Using the Biological Quality Element "Phytobenthos" and Harmonization with the Results of the Completed Intercalibration of the Med Gig (RM1, RM2, RM4); Greek National Water Monitoring Network, Joint Ministerial Decision 140384/2011; Special Secretariat for Waters, Ministry of Environment and Energy Institute of Marine Biological Resources and Inland Waters: Athens, Greece, 2016 ; p. 19.

35. Papastergiadou, E. Sampling and Analysis of River Macrophytes (Prefectures of Eastern Macedonia and Thrace, Epirus, Thessaly, Peloponnese and Western Greece); Technical Report; University of Patras, Department of Biology: Patras, Greece, 2015.

36. Zogaris, S.; Tachos, V.; Economou, A.N.; Chatzinikolaou, Y.; Koutsikos, N.; Schmutz, S. A model-based fish bioassessment index for Eastern Mediterranean rivers: Application in a biogeographically diverse area. Sci. Total Environ. 2018, 622, 676-689. [CrossRef] [PubMed]

37. Skoulikidis, N. Defining chemical status of a temporal Mediterranean River. J. Environ. Monit. 2008, 10, 842-852. [CrossRef]

38. Raven, P.; Holmes, N.; Dawson, F.; Everard, M. Quality assessment using river habitat survey data. Aquat. Conserv. 1998, 8, 477-499. [CrossRef]

39. Skoulikidis, N.T.; Lampou, A.; Laschou, S. Unraveling Aquatic Quality Controls of a Nearly Undisturbed Mediterranean Island (Samothraki, Greece). Water 2020, 12, 473. [CrossRef]

40. Prochaska, C.; Zouboulis, A. A Mini-Review of Urban Wastewater Treatment in Greece: History, Development and Future Challenges. Sustainability 2020, 12, 6133. [CrossRef]

41. SPSS Inc. PASW Statistics for Windows; Version 18.0; SPSS Inc.: Chicago, IL, USA, 2009. 
42. WISE Database. Available online: https://www.eea.europa.eu/data-and-maps/dashboards/wise-wfd (accessed on 10 February 2021).

43. Lazaridou-Dimitriadou, M.; Artemiadou, V.; Yfantis, G.; Mourelatos, S.; Mylopoulos, Y. Contribution to the ecological quality of Aliakmon river (Macedonia, Greece): A multivariate approach. Hydrobiologia 2000, 410, 47-58. [CrossRef]

44. Lazaridou-Dimitriadou, M. Seasonal variation of the water quality of rivers and streams of Eastern Mediterranean. Web Ecol. 2002, 3, 20-32. [CrossRef]

45. Chatzinikolaou, Y.; Dakos, V.; Lazaridou, M. Longitudinal impacts of anthropogenic pressures on benthic macroinvertebrate assemblages in a large transboundary Mediterranean river during the low flow period. Acta Hydrochim. Hydrobiol. 2006, 34, 453-463. [CrossRef]

46. Chatzinikolaou, Y.; Dakos, V.; Lazaridou, M. Assessing the Ecological Integrity of a Major Transboundary Mediterranean River Based on Environmental Habitat Variables and Benthic Macroinvertebrates (Aoos-Vjose River, Greece-Albania). Int. Rev. Hydrobiol. 2008, 93, 73-87. [CrossRef]

47. Patsia, A.; Kanli, L.; Agelakou, G.; Kasapi, K.A.; Albanakis, K.; Lazaridou, M. Ecological study of running waters of the Greek part of Nestos catchment area according to the WFD in April 2008. In Proceedings of the 3rd Panhellenic Congress on the Panhellenic Union of Bioscientists, Thessaloniki, Greece, 26-28 September 2008.

48. Brodersen, M.; Oikonomidis, G.; Simeliadou, E.; Almpanakis, K.; Lazaridou, M. Ecological water quality of the kompsatos river drainage basin (NE Greece). In Proceedings of the Protection and Restoration of the Environment XI Conference, Thessaloniki, Greece, 3-6 July 2012; pp. 423-432.

49. Lampou, A. Assessment of the Ecological Water Quality, according to the Directive 2000/60/EC, in Rivers of Samothraki Island in 2011. Master's Thesis, Aristotle University of Thessaloniki, Thessaloniki, Greece, 2012; p. 158.

50. Skoulikidis, N.; Lampou, A.; Karaouzas, I.; Gritzalis, K.; Lazaridou, M.; Zogaris, S. Stream ecological assessment on an Aegean island: Insights from an exploratory application on Samothraki (Greece). Fresenius Environ. Bull. 2014, 23, 1173-1182. [CrossRef]

51. Karaouzas, I.; Theodoropoulos, C.; Vardakas, L.; Zogaris, S.; Skoulikidis, N. The Evrotas River Basin: 10 Years of Ecological Monitoring. In The Rivers of Greece, 1st ed.; Skoulikidis, N., Dimitriou, E., Karaouzas, I., Eds.; Springer: Berlin/Heidelberg, Germany, 2018; pp. 279-326. ISBN 978-3-662-55369-5. [CrossRef]

52. Vigiak, O.; Grizzetti, B.; Udias-Moinelo, A.; Zanni, M.; Dorati, C.; Bouraoui, F.; Pistocchi, A. Predicting biochemical oxygen demand in European freshwater bodies. Sci. Total Environ. 2019, 666, 1089-1105. [CrossRef] [PubMed]

53. Meteo. All about Weather. Available online: https:/ /www.meteo.gr/index-en.cfm (accessed on 2 February 2021).

54. FAO. Food and Agriculture Organization of the United Nations. FAOSTAT. Agri-Environmental Indicators-Fertilizers Indicators. Available online: http:/ / www.fao.org/faostat/en/\#compare (accessed on 12 February 2021).

55. World Bank. World Bank National Accounts Data, and OECD National Accounts Data Files. Available online: https://data. worldbank.org/indicator/NY.GDP.MKTP.KD.ZG?locations=GR (accessed on 12 February 2020).

56. EC. Report on the Implementation of Council Directive 91/676/EEC Concerning the Protection of Waters against Pollution Caused by Nitrates from Agricultural Sources; Synthesis from year 2000 Member States reports; European Commission: Brussels, Belgium, 2002.

57. EC. Report on the Implementation of Council Directive 91/676/EEC on the Protection of Waters against Pollution Caused by Nitrates from Agricultural Sources Based on the Reports Submitted by the Member States in 2008-2011; European Commission: Brussels, Belgium, 2013.

58. EC. Report on the Implementation of Council Directive 91/676/EEC Concerning the Protection of Waters against Pollution Caused by Nitrates from Agricultural Sources Based on Member State Reports for the Period 2012-2015; European Commission: Brussels, Belgium, 2018.

59. EC. The EU Environmental Implementation Review 2019; Country Report-Bulgaria; European Commission: Brussels, Belgium, 2019.

60. Giouri, A.; Vavelidis, M.; Melfos, V.; Christophoridis, C. Geochemical study of the Bogdanas river waters at the Assiros- Lagada area, northern Greece. J. Environ. Prot. Ecol. 2010, 11, 424-433.

61. Lampou, A.; Skoulikidis, N.; Papadoulakis, V.; Vardakas, L. Evaluation of the waters' Condition in the Final Receiver of the Wastewater Treatment Plant in Municipality of Sparta. In Proceedings of the 11th Panhellenic Symposium of Oceanography \& Fisheries, Mytilini, Greece, 13-17 May 2015; pp. 661-664.

62. UNECE. Environmental Performance Review North Macedonia. UN Economic Commission for Europe, 3rd ed.; Environmental Performance Review Series 34; UN: New York, NY, USA, 2019.

63. Dimitriou, E.; Mentzafou, A.; Zogaris, S.; Tzortziou, M.; Gritzalis, K.; Karaouzas, I.; Nikolaidis, C. Assessing the environmental status and identifying the dominant pressures of a trans-boundary river catchment, to facilitate efficient management and mitigation practices. Environ. Earth Sci. 2012, 66, 1839-1852. [CrossRef]

64. Featherstone, K. Introduction: 'modernization' and the structural constrains of Greek politics. West Eur. Politics 2005, 28, 223-241. [CrossRef]

65. Demetropoulou, L.; Nikolaidis, N.; Papadoulakis, V.; Tsakiris, K.; Koussouris, T.; Kalogerakis, N.; Koukaras, K.; Chatzinikolaou, A.; Theodoropoulos, K. Water framework directive implementation in Greece: Introducing participation in water governance-the case of the Evrotas River Basin management plan. Environ. Policy Gov. 2010, 20, 336-349. [CrossRef] 
66. Zikos, D.; Bithas, K. The case of 'Weak Water' Governance Model: Athens-Greece. In Proceedings of the IASME/WSEAS International Conference on Water Resources, Hydraulics and Hydrology, Chalkida, Greece, 11-13 May 2006.

67. Kanakoudis, V.; Tsitsifli, S.; Azariadi, T. Overview of the River Basin Management Plans Developed in Greece Under the Context of the Water Framework Directive 2000/60/EC Focusing on the Economic Analysis. Water Resour. Manag. 2015, 29, 3149-3174. [CrossRef]

68. EC. A Blueprint to Safeguard Europe's Water Resources; European Commission: Brussels, Belgium, 2012.

69. Kanakoudis, V.; Tsitsifli, S.; Kouziakis, C.; Lappos, S. Defining the level of the Non-Revenue Water in the city of Kozani, Greece: Is it a typical case? Desalin Water Treat. 2014. [CrossRef]

70. Demetropoulou, L.; Lilli, M.A.; Petousi, I.; Nikolaou, T.; Fountoulakis, M.; Kritsotakis, M.; Panakoulia, S.; Giannakis, G.V.; Manios, T.; Nikolaidis, N.P. Innovative methodology for the prioritization of the Program of Measures for integrated water resources management of the Region of Crete, Greece. Sci. Total Environ. 2019, 672, 61-70. [CrossRef] [PubMed]

71. Spiliotis, M.; Panagiotou, L.; Kagalou, I.; Latinopoulos, D. A Fuzzified Multicriteria Outranking Method for Water Framework Directive Implementation in a Heavily Modified Urban Lake (Pamvotis, Greece). Water Resour. Manag. 2020. [CrossRef]

72. Arle, J.; Mohaupt, V.; Kirst, I. Monitoring of Surface Waters in Germany under the Water Framework Directive-A Review of Approaches, Methods and Results. Water 2016, 8, 217. [CrossRef]

73. Skoulikidis, N.T.; Sabater, S.; Datry, T.; Morais, M.; Buffagni, A.; Dörflinger, G.; Zogaris, S.; Sánchez-Montoya, M.M.; Bonada, N.; Kalogianni, E.; et al. Non-perennial Mediterranean rivers in Europe: Status, pressures, and challenges for research and management. Sci. Total Environ. 2017, 577, 1-18. [CrossRef] [PubMed]

74. Stubbington, R.; Chadd, R.; Núria, C.; Csabai, Z.; Miliša, M.; Morais, M.; Munné, A.; Pařil, P.; Pešić, V.; Tziortzis, I.; et al. Biomonitoring of intermittent rivers and ephemeral streams in Europe: Current practice and priorities to enhance ecological status assessments. Sci. Total Environ. 2018, 618, 1096-1113. [CrossRef]

75. Mamasis, N.; Eustratiadis, A.; Koukouvinos, A.; Koutsogiannis, D. Technical Report for the Development of a National Monitoring System of Surface Water Resources; Open Hydrosystem Information Network (OpenHi.net); Sector of Water Resources and Environment, National Technical University of Athens: Athens, Greece, 2019; p. 43.

76. Skoulikidis, N.; Lampou, A.; Katopodis, G. Water Metabolism and Water Management. In Samothraki as a Biosphere Reserve (SamoMAB); Dominik, N., Ed.; Report to the Austrian Academy of Sciences; University of Natural Resources and Life Sciences: Vienna, Austria, 2019; pp. 5-36. ISBN 978-3-7001-8498-0.

77. Pisinaras, V.; Panagopoulos, A.; Herrmann, F.; Bogena, H.R.; Doulgeris, C.; Ilias, A.; Tziritis, E.; Wendland, F. Hydrologic and geochemical research at Pinios Hydrologic Observatory: Initial results. Vadose Zone J. 2018, 17, 180102. [CrossRef]

78. MEE. Methodology for the analysis of anthropogenic pressures and impacts on surface and groundwater bodies. In 1st Update of the River Basin Management Plans of the 14 Water Districts (EL); Ministry of Environment \& Energy: Athens, Greece, 2016.

79. EC. Analysis of Pressures and Impacts. Guidance Document No 3; Common Implementation Strategy for the Water Framework Directive (2000/60/EC); European Communities: Luxembourg, 2003.

80. Kagalou, I.; Latinopoulos, D. Filling the Gap between Ecosystem Services Concept and River Basin Management Plans: The Case of Greece in WFD 20+. Sustainability 2020, 12, 7710. [CrossRef]

81. EEA. European Waters Assessment of Status and Pressures; European Environmental Agency: Luxembourg, 2018.

82. Dottori, F.; Mentaschi, L.; Bianchi, A.; Alfieri, L.; Feyen, L. Adapting to Rising River Flood Risk in the EU under Climate Change; Publications Office of the European Union: Luxembourg, 2020; ISBN 978-92-76-12946-2. [CrossRef] 